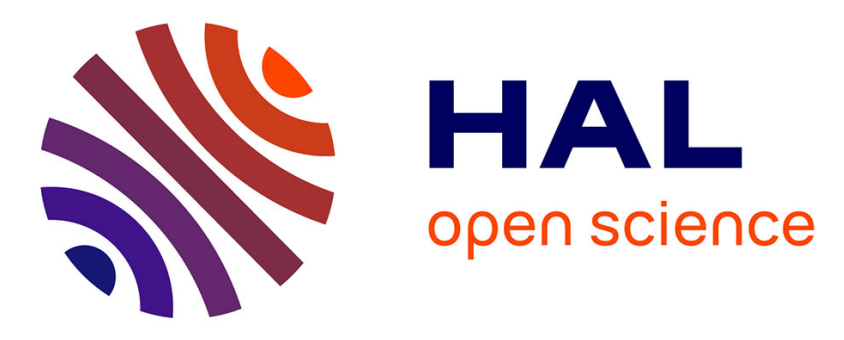

\title{
Do DOM optical parameters improve the prediction of copper availability in vineyard soils?
}

Frédéric Ouédraogo, Jean-Yves Cornu, Noémie Janot, Christophe Nguyen, Mahaut Sourzac, Edith Parlanti, Laurence Denaix

\section{- To cite this version:}

Frédéric Ouédraogo, Jean-Yves Cornu, Noémie Janot, Christophe Nguyen, Mahaut Sourzac, et al.. Do DOM optical parameters improve the prediction of copper availability in vineyard soils? Environmental Science and Pollution Research, 2022, 10.1007/s11356-021-16361-5 . hal-03348974

\section{HAL Id: hal-03348974 \\ https://hal.science/hal-03348974}

Submitted on 20 Sep 2021

HAL is a multi-disciplinary open access archive for the deposit and dissemination of scientific research documents, whether they are published or not. The documents may come from teaching and research institutions in France or abroad, or from public or private research centers.
L'archive ouverte pluridisciplinaire HAL, est destinée au dépôt et à la diffusion de documents scientifiques de niveau recherche, publiés ou non, émanant des établissements d'enseignement et de recherche français ou étrangers, des laboratoires publics ou privés. 
1 Do DOM optical parameters improve the prediction of copper availability

2 in vineyard soils?

3

4 Frédéric Ouedraogo ${ }^{1,2, *}$, Jean-Yves Cornu ${ }^{1}$, Noémie Janot ${ }^{1}$, Christophe Nguyen ${ }^{1}$, Mahaut 5 Sourzac $^{2}$, Edith Parlanti ${ }^{2}$, Laurence Denaix ${ }^{1}$

6

$7 \quad{ }^{1}$ ISPA, INRAE, Bordeaux Sciences Agro, 33140, Villenave d'Ornon, France

$8 \quad{ }^{2}$ University of Bordeaux, UMR CNRS 5805, EPOC, 33400, Talence, France

9

$10 *$ Corresponding author: Frédéric Ouedraogo

11 Tel: 0557122446

12 Fax : 0557122510

13 E-mail : frederic.ouedraogo@inrae.fr

14

15

16

17

18

19 
Accumulation of copper $(\mathrm{Cu})$ in soils due to the application of fungicides may be toxic for organisms and hence affect winegrowing sustainability. Soil parameters such as $\mathrm{pH}$ and dissolved organic matter (DOM) are known to affect the availability of $\mathrm{Cu}$. In this study, we investigated the contribution of chromophoric and fluorescent DOM properties to the prediction of $\mathrm{Cu}$ availability in 18 organic vineyard soils in the Bordeaux winegrowing area (France). The DOM parameters, assessed through absorbance and fluorescence analyses, and proxies for $\mathrm{Cu}$ availability (total soluble $\mathrm{Cu}$ and free ionic $\mathrm{Cu}^{2+}$ ) were measured in $0.01 \mathrm{M} \mathrm{KCl}$ extracts. Total soluble $\mathrm{Cu}\left(\mathrm{Cu}_{\mathrm{KCl}}\right)$ varied 23-fold while free ionic $\mathrm{Cu}^{2+}$ varied by a factor of 4,600 among the soils. DOC concentrations were similar among the soils, but the samples differed in the quality of DOM as assessed by optical spectroscopy. Multilinear regression models with and without DOM quality parameters were investigated to predict $\mathrm{Cu}$ availability. The best model for $\mathrm{Cu}$ KCl successfully explained $83 \%$ of variance and included $\mathrm{pH}, \mathrm{Cu}_{\mathrm{T}}$ and two $\mathrm{DOM}$ fluorescence quality indices, the FI fluorescence index, which distinguishes between microbial and higher plant origins, and the HIX humification index. For the prediction of $\mathrm{Cu}^{2+}, \mathrm{pH}$ alone explained $88 \%$ of variance and adding DOM parameters did not improve modelling. The two $\mathrm{Cu}$ availability proxies were related to $\mathrm{pH}$. This study confirms the prominent role of $\mathrm{pH}$ in $\mathrm{Cu}$ availability and underlines the importance of DOM quality to better predict $\mathrm{Cu}$ solubility.

\section{Keywords}

41 Copper, organic matter, fluorescence, absorbance, vineyard soils, availability, modelling. 
Copper-based fungicides like Bordeaux mixture have been repeatedly applied in vineyards since the end of the $19^{\text {th }}$ century to control downy mildew of grapevine, sometimes causing $\mathrm{Cu}$ to accumulate in the soils (Brun et al. 2001; Ballabio et al. 2018). In European soils, the median of total $\mathrm{Cu}$ concentrations is $13 \mathrm{mg} \mathrm{kg}^{-1}$. In vineyards soils, this value reaches 49 and $91 \mathrm{mg} \mathrm{kg}^{-}$ ${ }^{1}$ in Europe and France, respectively (Ballabio et al. 2018). In old vineyards, Cu concentrations in the topsoil can reach several hundred $\mathrm{mg} \mathrm{Cu} \mathrm{kg}{ }^{-1}$, as widely reported in several European countries including France, Italy, Spain, Greece, Portugal, Czech Republic (Fernández-Calviño et al. 2009; Komárek et al. 2010; Fernández-Calviño et al. 2010; Flores-Álvarez et al. 2011; Kelepertzis et al. 2017). Despite the reduction of the authorized application rate to $4 \mathrm{~kg} \mathrm{Cu} \mathrm{ha-}$ ${ }^{1}$ year $^{-1}$ (EFSA et al. 2018), Cu-based fungicides continue to be used, particularly in organic viticulture for which there is currently no alternative that offers equally effective protection (Andrivon et al. 2018).

$\mathrm{Cu}$ is an essential micronutrient for all living organisms. Microorganisms need trace levels of $\mathrm{Cu}$ for their growth because it is a cofactor in enzymatic reactions (Trevors and Cotter 1990). In plants, copper plays key roles in cell wall metabolism and in photosynthetic electron transport (Yruela 2009). A Cu deficiency can affect vital functions in plant metabolism. However, excess copper can cause phytotoxicity through the formation of oxygen radicals which damage cells and inactivate protein structure, or by disturbing photosynthetic activity due to the photoinhibition induced by excessive $\mathrm{Cu}$ (Yruela 2005). In calcareous soils, excess $\mathrm{Cu}$ can also lead to Fe deficiency in graminaceous species such as durum wheat (Michaud et al. 2007) since $\mathrm{Cu}(\mathrm{II})$ has sufficient affinity for phytosiderophores to divert them from their initial objective of mobilising $\mathrm{Fe}(\mathrm{III})$. All these problems may affect plant growth and reduce agricultural productivity. $\mathrm{Cu}$ phytotoxicity has been reported in durum wheat grown in former vineyard soils with total $\mathrm{Cu}$ concentrations beginning at $114 \mathrm{mg} \mathrm{kg}^{-1}$ (Michaud et al. 2007). Exposure to 
$\mathrm{Cu}$ at soil concentrations above $16 \mathrm{mg} \mathrm{Cu} \mathrm{kg}^{-1}$ in the soil has also been shown to have a serious impact on earthworm Eisenia fetida reproduction by reducing the production of cocoons (Helling et al. 2000). Fernández-Calviño et al. (2010) reported that microbial enzymatic activity (phosphatase) in Portuguese vineyard soils decreased drastically above $250 \mathrm{mg} \mathrm{Cu} \mathrm{kg}{ }^{-1}$. A recent meta-analysis of $\mathrm{Cu}$ in vineyard soils showed that microbial respiration was reduced by half above a stock of $200 \mathrm{~kg} \mathrm{Cu} \mathrm{ha}^{-1}$ (Karimi et al. 2021). Excess copper may thus cause ecotoxicity in vineyard soils, although the ecotoxic thresholds vary widely depending on certain soil parameters like organic matter $(\mathrm{OM})$ content or $\mathrm{pH}$. Total $\mathrm{Cu}$ inducing $50 \%$ of biomass decrease $\left(\mathrm{EC}_{50}\right)$ is a widely used indicator in ecotoxicity studies. It has been shown that $\mathrm{EC}_{50}$ of lettuce and tomatoes increases with increasing OM content or decreasing pH (Recatalá et al. 2012; Sacristán et al. 2016). Cu toxicity may therefore be linked not only to total $\mathrm{Cu}$ amounts but also to certain bioavailable forms of $\mathrm{Cu}$ in the soils.

The bioavailability of metals is defined as the fraction of its environmentally available compound an organism takes up through physiologically driven processes (ISO 2006). Environmental availability is defined as the availability of metals in the soil measured using chemical methods (Harmsen 2007). Sauvé et al. (1996) showed that $\mathrm{Cu}$ concentrations in the tissues of several plants were closely linked to $\mathrm{Cu}$ in solution, more specifically to free $\mathrm{Cu}^{2+}$ activity. The free ion $\mathrm{Cu}^{2+}$ is thought to be the bioavailable form, and this hypothesis is supported by other authors who reported that $\mathrm{Cu}$ toxicity for different organisms (algae, earthworms, zooplankton) in soils and aquatic systems depended strongly on free $\mathrm{Cu}^{2+}$ activity (Verweij et al. 1992; Qiu et al. 2013; Tait et al. 2016).

The concentration of $\mathrm{Cu}$ in soil solutions and $\mathrm{Cu}^{2+}$ activity are controlled by soil properties such as total $\mathrm{Cu}$ content, $\mathrm{pH}$ and soil organic matter (SOM) content (Sauvé et al. 1997; Sauvé et al. 2000). $\mathrm{pH}$ is known to affect $\mathrm{Cu}$ solubility (Temminghoff et al. 1994), but also copper speciation in solution (Bravin et al. 2009). Cu biogeochemistry is controlled to a large extent 
by its binding to organic matter, since SOM contains acidic functional groups (mainly phenolic and carboxylic groups) which have a particular and strong affinity for $\mathrm{Cu}$ (Manceau and Matynia 2010). Organic matter supplied to soils in different forms (fresh materials, compost, manure, sludge) has been shown to significantly reduce $\mathrm{Cu}$ availability in its soluble form (Navel and Martins 2014; Ferreira et al. 2018; Gonzaga et al. 2020) and its ionic form (Oustriere et al. 2016). Dissolved organic matter (DOM) plays a key role in the fate of metals in the soil. While SOM immobilises $\mathrm{Cu}$ through sorption onto solid phases (Sauvé et al. 2000), DOM increases $\mathrm{Cu}$ solubility by forming $\mathrm{Cu}$ complexes in soil solution. However, the free $\mathrm{Cu}$ fraction may also decrease due to complexation with DOM. Cu mobilisation from the solid phase into solution has been reported to be exacerbated with increasing aromatic DOM (Amery et al. 2007; Amery et al. 2008; Araújo et al. 2019). What is more, prediction of $\mathrm{Cu}$ in soil leachates was improved when the DOM aromaticity was taken into account in geochemical modelling (Amery et al. 2008) rather than only considering a percentage of reactive DOM (Djae et al. 2017). Phenolic and $\mathrm{O}$-functional groups of aromatic molecules have high affinity for $\mathrm{Cu}$ binding and are highly stable, which may facilitate its solubilisation by DOM (Fuentes et al. 2013). These findings clearly underline the importance of DOM characteristics in the control of $\mathrm{Cu}$ dynamics in soil solutions.

The capacity of DOM to complex $\mathrm{Cu}$ and to promote its mobilisation from the solid phase not only depends on DOM quantity, but also on DOM quality (Baken et al. 2011; He et al. 2016; Kikuchi et al. 2017). DOM quality can be described through its optical properties assessed by Ultraviolet visible (UV-Vis) absorption and excitation-emission matrix (EEM) fluorescence spectroscopy (Jaffé et al. 2014). In the soil literature, DOM is largely characterised by its specific UV-absorbance index at $254 \mathrm{~nm}\left(\mathrm{SUVA}_{254}\right)$, which is related to its aromaticity (Weishaar et al. 2003). But the measurements of $\mathrm{SUVA}_{254}$ may be biased due to the presence of colloids or iron at high concentrations (Weishaar et al. 2003). Other spectroscopic indices 
117 are widely used in studies on aquatic environments to characterise DOM (Yang and Hur 2014;

118 Derrien et al. 2017) and its interactions with $\mathrm{Cu}$ (He et al. 2016). Another UV-Vis absorption

119 index is the spectral slope ratio $\mathrm{S}_{\mathrm{R}}$ which is inversely proportional to molecular size (Helms et

120 al. 2008). Fluorescence indices include the humification index HIX, which expresses the degree

121 of DOM condensation (Zsolnay et al. 1999), the biological index BIX, used to assess the recent

122 production of autochthonous components (Huguet et al. 2009), and the fluorescence index FI

123 which makes it possible to distinguish microbial versus higher plant origin of DOM (McKnight

124 et al. 2001). In aquatic media, concentrations of metals ( $\mathrm{Cu}, \mathrm{Zn}, \mathrm{Cd})$ in sediment solutions were

125 shown to be related to DOM aromaticity (HIX) and to the autochthonous (BIX) or microbial

126 (FI) origins of molecules and not to DOM molecular size $\left(\mathrm{S}_{\mathrm{R}}\right)$ (He et al. 2016; Zhang et al.

127 2020).

128 Up to now, only a few studies combined all these tools to describe DOM in contrasted

129 agricultural soils (Romero et al. 2017; Li et al. 2019; Sun et al. 2020) and their effects on metal

130 speciation in soil solution (Guo et al. 2015) or sediments (Xu et al. 2019). To our knowledge,

131 only one paper reported the use of these spectroscopic indices for vineyard soils exposed to

132 herbicide glyphosate and Cu-based fungicides (Daouk et al. 2015). The main goal of the present

133 study was thus to examine the contribution of quality of DOM in predicting $\mathrm{Cu}$ availability in

134 organic vineyard soils. We hypothesized that taking the DOM optical indices into account

135 would improve the prediction of $\mathrm{Cu}$ environmental availability, assessed with total soluble $\mathrm{Cu}$

136 or free $\mathrm{Cu}^{2+}$.

2. Material and methods

\subsection{Soil sampling and analyses}

139 Eighteen vineyard topsoils were sampled in the vine inter-rows at a depth of between 0 and 15 cm in March 2019 in the region of Bordeaux (France), located in the AOC (i.e., controlled 
141 designation of origin) zones of 'Bordeaux supérieur', 'Blaye Côtes de Bordeaux' and 'Graves'.

142 All the vineyards sampled are organic and the only fungicide treatment they receive is $\mathrm{Cu}$. The

143 fungicide applied was mainly Bordeaux mixture (mixture of copper sulphate and lime).

144 The 18 soils were contrasted in terms of organic matter and $\mathrm{pH}$ based on the pedological

145 bedrock and agronomic practices. After sampling, the fresh soils were sieved to $4 \mathrm{~mm}$ and kept

146 at $4{ }^{\circ} \mathrm{C}$ before analysis to minimise the effects of sampling on dissolved organic carbon (Jones

147 and Willett 2006).

148 Soil $\mathrm{pH}\left(\mathrm{pH}_{\text {water }}\right)$, total copper $\left(\mathrm{Cu}_{\mathrm{T}}\right)$, organic carbon $\left(\mathrm{C}_{\text {org }}\right)$ and total nitrogen contents were

149 determined on separate air-dried soils. $\mathrm{pH}_{\text {water }}$ was determined by potentiometry in distilled

150 water in a 1:2.5 (w/v) soil-to-solution ratio (NF ISO 10390). $\mathrm{Cu}_{\mathrm{T}}$ was determined after aqua

151 regia microwave-assisted digestion (Anton Paar Multiwave PRO Microwave Reaction

152 System $\left.{ }^{\circledR}\right)$. Aliquots $(0.5 \mathrm{~g})$ of crushed dried sample were placed in a microwave Teflon flask

153 with an acid mix $\mathrm{HNO}_{3}: \mathrm{HCl}\left(3.75: 1.25\right.$, v:v) (Aristar ${ }^{\circledR}$ for trace analysis, VWR Chemicals).

154 Extracts were obtained after centrifugation at $1,300 \mathrm{~W}$ at $180^{\circ} \mathrm{C}$ for 20 minutes and filtration

155 on a $2-\mu \mathrm{m}$ Whatman cellulose acetate filter. The concentration of $\mathrm{Cu}$ in the extracts was

156 measured by ICP-OES (Agilent $\left.{ }^{\circledR}\right)$. A certified reference material $(\mathrm{BCR}-143 \mathrm{R}, 98 \% \mathrm{Cu}$

157 recovery rate) was used to validate extraction and quantification.

$158 \mathrm{C}_{\text {org }}$ and $\mathrm{N}$ contents in soils were assessed by dry combustion $\left(950^{\circ} \mathrm{C}\right)$ with a $\mathrm{CN}$ analyser

159 (Flashea 1112 series $\left.{ }^{\circledR}\right)$ after carbonates were removed with $\mathrm{HCl}$ (NF ISO 10694). An organic

160 soil (ISE 973) was used as control.

\subsection{Extraction of soil solutions}

162 Before the soil solution was extracted, the wet soils were all adjusted to $80 \%$ water holding

163 capacity (WHC) and incubated at $20^{\circ} \mathrm{C}$ for one week to avoid a possible microbial flush and

164 its effects on $\mathrm{Cu}$ solubility and speciation (Cornu et al. 2007). 
165 Soil solutions were extracted as follows: $15 \mathrm{~g}$ of wet soil were shaken with $30 \mathrm{~mL}$ of $0.01 \mathrm{M}$

$166 \mathrm{KCl}$ (purity $99.5 \%$, Merck ${ }^{\circledR}$ ) with $1: 2 \mathrm{w} / \mathrm{v}$ (soil-to-solution ratio) at $35 \mathrm{rev} . \mathrm{mn}^{-1}$ for $2 \mathrm{~h}$. The 167 soil suspensions were centrifuged at $4,600 \mathrm{~g}$ for $10 \mathrm{~min}$. The supernatants were collected and

168 filtered through $0.2 \mu \mathrm{m}$ cellulose acetate filters. Extractions were performed in triplicate. The 169 extracted soil solutions were stored at $4{ }^{\circ} \mathrm{C}$ in the dark before spectroscopic analysis, which was 170 performed less than seven days after extraction.

171 The $0.01 \mathrm{M} \mathrm{KCl}$ extraction was chosen for two reasons: (i) to be in the range of common ionic

172 strength for soil pore water and (ii) to avoid DOM coagulation which may occur in the case of $173 \mathrm{CaCl}_{2}$ extraction (Römkens and Dolfing 1998). The 1:2 w/v ratio was used because lower 174 extraction ratios tend to overestimate the concentrations of DOC recovered (Jones and Willett 175 2006).

\subsection{Analyses of soil extracts}

2.3.1 Total dissolved metals and $\mathrm{Cu}^{2+}$ concentrations

178 The $\mathrm{pH}$ of the extracts $\left(\mathrm{pH}_{\mathrm{KCl}}\right)$ was measured immediately after extraction by potentiometry using a microelectrode (E16M331, Radiometer Analytical $\left.{ }^{\circledR}\right)$. The total concentrations of

180 dissolved $\mathrm{Ca}, \mathrm{Cu}, \mathrm{Fe}, \mathrm{Mn}$ and $\mathrm{Zn}$ were determined by ICP-OES (Agilent ${ }^{\circledR}$ ) in a 5-mL aliquot 181 acidified with $2 \% \mathrm{HNO}_{3}$ (Aristar ${ }^{\circledR}$ for trace analysis purity $69 \%$, VWR Chemicals ${ }^{\circledR}$ ). Free

$182 \mathrm{Cu}$ activity was measured in non-acidified 5-mL aliquots using a cupric ion-selective electrode (ISE, 9629BNWP, Thermo Scientific Orion ${ }^{\circledR}$ ). The ISE was calibrated in Cu solutions buffered

184 with iminodiacetic acid and potassium phthalate with $\mathrm{pCu}\left(=-\log _{10} \mathrm{aCu}^{2+}\right)$ ranging from 5.5 to 18513 as described in (Bravin et al. 2009). The calibration curve $\left(\mathrm{R}^{2}=0.98, \mathrm{n}=67\right)$ showed $85 \%$ 186 slope efficiency compared to the theoretical Nernstian slope (Fig. S1). The concentrations of 187 free $\mathrm{Cu}^{2+}$ were determined from $\mathrm{pCu}$ values and from the $\mathrm{Cu}^{2+}$ activity coefficient, calculated 188 from the extended Debye-Hückel equation (Ritsema 1993). 
190 The concentrations of dissolved organic carbon (DOC) in the soil extracts were determined

191 using a TOC analyser (TOC-VCPH, Shimadzu ${ }^{\circledR}$, Japan). The DOC was calculated as the

192 difference between total carbon (TC) and inorganic carbon (IC) (DOC=TC - IC). The analyser

193 was calibrated with a solution prepared from sodium carbonate, sodium bicarbonate, potassium

194 hydrogen phthalate, and the $0.01 \mathrm{M} \mathrm{KCl}$ was used as the zero point in the calibration.

\section{Absorbance indices}

196 Soil solution UV-visible absorbance was measured using a Jasco ${ }^{\circledR}$ V-560 spectrophotometer,

197 scanning from 210 to $700 \mathrm{~nm}$ with a $0.5 \mathrm{~cm}$ path length quartz cuvette. A $0.01 \mathrm{M} \mathrm{KCl}$ solution

198 was used as a blank. Several indices were determined from absorbance spectra to characterise

199 the DOM in the extracts. The specific UV absorbance at $254 \mathrm{~nm}\left(\mathrm{SUVA}_{254}, \mathrm{~L} \mathrm{gC}^{-1} \mathrm{~cm}^{-1}\right)$ was

200 calculated as follows:

$201 \quad \mathrm{SUVA}_{254}=\frac{\mathrm{A}_{254} \cdot 1000}{\mathrm{~b} \cdot \mathrm{DOC}}$

202 where $\mathrm{A}_{254}$ is the measured absorbance at $254 \mathrm{~nm}$ (dimensionless) (Fig. S2), b is the path length 203 (cm) and DOC the organic carbon concentration $\left(\mathrm{mg} \mathrm{L}^{-1}\right)$.

204 The $\mathrm{S}_{\mathrm{R}}$ index was calculated as the spectral slope ratio over $275-295 \mathrm{~nm}$ to $350-400 \mathrm{~nm}$ (Helms 205 et al. 2008).

\section{Fluorescence indices}

207 The excitation-emission matrix (EEM) fluorescence spectra were recorded in a $0.5 \mathrm{~cm}$ quartz cuvette, thermostatted at $20^{\circ} \mathrm{C}$ in the cell holder, using an Aqualog spectrofluorometer (Horiba Scientific $($ ). Excitation scans were performed using a double-grating monochromator, a 150-

210 Watt Xenon lamp with a $5 \mathrm{~nm}$ bandpass, and 2-s integration time at wavelengths of 240-800 $\mathrm{nm}$ 211 at 5-nm intervals. Emission spectra were collected with high CCD detector gain at 
212 approximately $0.58 \mathrm{~nm}$ (1 pixel) intervals at wavelengths of $245-830 \mathrm{~nm}$. A blank EEM was 213 acquired daily from the $0.01 \mathrm{M} \mathrm{KCl}$ solution used for soil extraction and subtracted from EEM 214 spectra of all the samples to eliminate scattering peaks. EEM spectra were corrected for 215 instrumental biases. When the maximum intensity of the absorbance spectrum was higher than 2160.1 , the samples were diluted with $0.01 \mathrm{M} \mathrm{KCl}$ to avoid inner filter effects. Fluorescence data 217 are expressed in Raman units (R.U) after normalization to the area under the Raman peak of an 218 ultrapure water blank (Milli-Q, Millipore ${ }^{\circledR}$ ) at an excitation wavelength of $350 \mathrm{~nm}$. TreatEEm software (https://sites.google.com/site/daromasoft/home/treateem) was used to remove remaining scatter peaks in EEMs and to calculate the fluorescence indices.

221 Several indices were obtained from fluorescence analysis. As defined by Zsolnay et al. (1999), 222 the humification index HIX was calculated as the ratio $\mathrm{H} / \mathrm{L}$ of the area under the curve for two spectral regions (between emission wavelengths $435 \mathrm{~nm}$ and $480 \mathrm{~nm}$ for $\mathrm{H}$ and between 300 $\mathrm{nm}$ and $345 \mathrm{~nm}$ for L) from the emission spectrum scanned for excitation at $254 \mathrm{~nm}$ (Fig. S3). The higher the HIX, the higher the degree of condensation and aromaticity. The biological index BIX was determined as the ratio of fluorescence intensity at an emission wavelength of $380 \mathrm{~nm}$ to that at $430 \mathrm{~nm}$, at an excitation wavelength of $310 \mathrm{~nm}$ (Huguet et al. 2009). High BIX values are related to predominantly recent production of DOM linked to biological activity (Huguet et et al. 2001). FI is an indicator of the source of DOM, low values are associated with vascular-

232 plant-derived compounds, while high values indicate microbial origin or microbially processed 233 terrestrial DOM (Cory and Mcknight 2005; Broder et al. 2017).

\subsection{Statistical analyses}

235 All statistical analyses were performed with R software version 4.0.2 (R core Team 2020). First, principal component analysis (PCA) was used to visualise correlations between variables and 
possibly groups of soils. PCA was performed using the 'FactomineR' package (Husson et al.

238 2008). For the PCA, all the variables were log-transformed except $\mathrm{pH}_{\text {water }}$ and $\mathrm{pH}_{\mathrm{KCl}}$. Second,

239 a correlation matrix was performed to investigate the relationships between the same variables

240 using the R 'corrplot' package (Wei and Simko 2021). The Pearson correlation coefficients

241 were considered as statistically significant at $\mathrm{p}<0.01$.

242 Multi-linear log-log regressions were used to identify and rank the contributions of soil 243 variables to the prediction of $\mathrm{Cu}$ availability proxies $\left(\mathrm{Cu}_{\mathrm{KCl}}\right.$ and $\left.\mathrm{Cu}^{2+}\right)$. Multi-linear regressions 244 were performed using the 'car' package (Fox and Weisberg 2019). Each replicate was 245 considered as one sample. For $\mathrm{Cu}_{\mathrm{KCl}}$ prediction, soil and solution variables were entered as 246 predictors $\left(\mathrm{Cu}_{\mathrm{T}}, \mathrm{pH}_{\text {water }}, \mathrm{C}: \mathrm{N}, \mathrm{C}_{\text {org }}, \mathrm{SUVA}_{254}, \mathrm{~S}_{\mathrm{R}}\right.$, DOC, HIX, BIX, FI). Only solution variables 247 were used for $\mathrm{Cu}^{2+}$ prediction $\left(\mathrm{Cu}_{\mathrm{KCl}}, \mathrm{pH}_{\mathrm{KCl}}, \mathrm{SUVA}_{254}, \mathrm{~S}_{\mathrm{R}}, \mathrm{DOC}, \mathrm{HIX}, \mathrm{BIX}, \mathrm{FI}\right)$. The variables 248 (except $\mathrm{pH}_{\text {water }}$ and $\mathrm{pH}_{\mathrm{KCl}}$ ) were log-transformed before the computation. A total of 2,047 and 249255 models with one to maximum four predictors (to avoid overparameterization) were 250 exhaustively tested for $\mathrm{Cu}_{\mathrm{KCl}}$ and $\mathrm{Cu}^{2+}$ predictions, respectively. The best models had the 251 maximum $\mathrm{R}^{2}$ adj (goodness of fit) with a minimum number of predictors (parsimony). The 252 selected models also had a variation inflation factor (VIF) below 2.3 to avoid multicollinearity. 253 The root mean square error (RMSE) was calculated to compare the accuracy of the models 254 including or not DOM parameters.

\subsection{Modelling $\mathrm{Cu}^{2+}$ activity}

$256 \mathrm{Cu}$ speciation in solution was predicted with ORCHESTRA software (Meeussen 2003) using the DOM ion-binding model NICA-Donnan (Kinniburgh et al. 1996; Koopal et al. 2005). The objective was to compare simulations of amounts of free $\mathrm{Cu}^{2+}$ with the corresponding 259 experimental measurements. The input parameters used for the calculations were $\mathrm{pH}_{\mathrm{KCl}}$, total 260 DOM, $\mathrm{Cu}^{2+}, \mathrm{Ca}^{2+}, \mathrm{Zn}^{2+}, \mathrm{Fe}^{3+}$ and $\mathrm{Mn}^{3+}$ concentrations. $\mathrm{Cl}^{-}$and $\mathrm{K}^{+}$concentrations were set to $0.01 \mathrm{M}$, i.e., their concentration in the extraction solution. DOM concentrations were calculated 
assuming that DOM contained $50 \%$ of C. Activity coefficients were calculated using the

263 Davies equation. Fe activity was calculated by assuming its equilibrium with $264 \mathrm{Fe}(\mathrm{OH})_{3}\left(\log \mathrm{K}_{\mathrm{S}}=3.19\right)$. Equilibrium reactions were described taking the equilibrium with 265 atmospheric $\mathrm{CO}_{2}\left(\mathrm{pCO}_{2}=3.9 \times 10^{-4} \mathrm{~atm}\right)$ into account.

266 Several hypotheses regarding DOM composition were examined: (i) $100 \%$ humic acids (HA), 267 (ii) $100 \%$ fulvic acids (FA), or an inert DOM pool and an active DOM pool comprised of (iii) $26865 \%$ FA, or (iv) $30 \%$ HA and $30 \%$ FA. In each case, proton and metal binding parameters 269 were set at their generic value (Milne et al. 2001, 2003). Sixty-five percent is the approximation 270 generally used to determine the amount of free metal cations in soil solutions (Weng et al. 2002, 271 Djae et al. 2017). In the second step, free $\mathrm{Cu}$ was optimised by adjusting the reactive DOM pool 272 (noted rDOM) in each sample to match the experimental measurements.

\section{Results and discussion}

\subsection{Soil properties}

The main soil parameters are listed in Table $\mathbf{1 .}$

277 Total concentration of $\mathrm{Cu}$ in the soil $\left(\mathrm{Cu}_{\mathrm{T}}\right)$ ranged from 28 to $238 \mathrm{mg} \mathrm{kg}^{-1}$ with a median of 107

$278 \mathrm{mg} \mathrm{kg}^{-1}$. In the Aquitaine region of France, large quantities of $\mathrm{Cu}$-based fungicides are used to 279 prevent downy mildew caused by the wet climate. Accordingly, El Hadri et al. (2012) found 280 that $\mathrm{Cu}_{\mathrm{T}}$ in soils in the Aquitaine region ranged from 0.5 to $491 \mathrm{mg} \mathrm{kg}^{-1}$, with maximum values 281 found in vineyard soils. All the vineyard soils in our study fell within this range. It is worth 282 noting that $\mathrm{Cu}_{\mathrm{T}}$ concentrations may be very different in the same location, mainly depending 283 on the age of the vineyard (Fernández-Calviño et al. 2009). This may explain the wide range of $284 \mathrm{Cu}_{\mathrm{T}}$ (i.e., 8-fold) observed in the present study. 
The $\mathrm{pH}_{\text {water }}$ of the soils ranged from 6.3 to 8.3 (Table 1). The most alkaline soils were associated

286 with the highest carbonate contents (Table 1). The organic carbon content $\left(\mathrm{C}_{\text {org }}\right)$ ranged from 2875 to $31 \mathrm{~g} \mathrm{~kg}^{-1}$. Vineyard soils are generally poor in organic carbon. Coll et al. (2011) reported

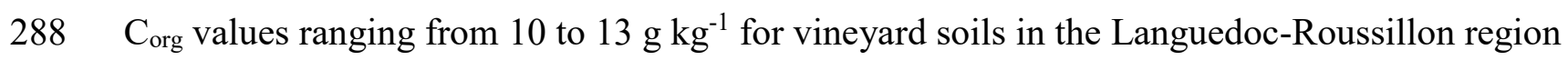
289 (South of France). Our results are also similar to those obtained by Parat et al. (2002) $\left(11<\mathrm{C}_{\text {org }}\right.$ $290<45 \mathrm{~g} \mathrm{~kg}^{-1}$ ) in a study conducted in Burgundy viticultural region (east-central France).

The C:N ratio varied between 10.3 and 17.4 (Table 1). The C:N ratio varied between 10.3 and 292 17.4 (Table 1). This ratio provides information on the rate of SOM mineralisation (high for 293 values below 12) and also on the carbon storage capacity of the soil (Swift et al. 1979).

\subsection{Elemental composition of the soil extracts and $\mathrm{Cu}$ availability}

Mean Fe, Mn, Ca and Zn concentrations are listed in Table S1 in supplementary information. The $\mathrm{pH}$ of the soil extracts $\left(\mathrm{pH}_{\mathrm{KCl}}\right)$ fluctuated between 5.9 and 7.6 (Table S1).

Mean concentrations of DOC in $\mathrm{KCl}$ extracts ranged only from 15 to $28 \mathrm{mg} \mathrm{L}^{-1}$ (median 18 )

(Table S1). This corresponds to 0.08 and $0.33 \%$ of total $\mathrm{C}_{\mathrm{org}}$, illustrating the low solubility of SOM. Furthermore, Zsolnay (1996) reported that DOC is the most mobile and reactive fraction 301 of $\mathrm{C}_{\text {org }}$.

The mean total concentration of $\mathrm{Cu}$ in the extracts $\left(\mathrm{Cu}_{\mathrm{KCl}}\right)$ ranged from 0.11 to $2.64 \mu \mathrm{M}$, i.e., a factor of 23 (Table S1), with a median of $0.3 \mu \mathrm{M}$. Many studies in the literature used salt solutions - generally $\mathrm{CaCl}_{2}$ - to extract $\mathrm{Cu}$ and considered it to be a correct surrogate for soil pore water $\mathrm{Cu}$ (Sauvé et al. 1997; Chaignon et al. 2003). Our $\mathrm{Cu}_{\mathrm{KCl}}$ values were similar to those 306 found by Djae et al. (2017) $\left(3 \times 10^{-2}-3.7 \mu \mathrm{M} \mathrm{Cu}\right)$ with $2 \mathrm{mM} \mathrm{KNO}_{3} / \mathrm{Ca}\left(\mathrm{NO}_{3}\right)_{2}$ extractions. 307 Similar ranges of total $\mathrm{Cu}$ assessed in $\mathrm{CaCl}_{2}$ extracts were found in the literature: $0.11-2 \mu \mathrm{M}$ 308 (Sauvé et al. 1996), 0.01 - $5 \mu \mathrm{M}$ (Sauvé et al. 1995). 
309 The mean $\mathrm{Cu}^{2+}$ concentrations varied between $2.1 \times 10^{-4}$ and $0.95 \mu \mathrm{M}$, i.e., by a factor of 4,600

310 (Table S1). This variability shows that our samples were more contrasted in terms of $\mathrm{Cu}^{2+}$ than

$311 \mathrm{Cu}_{\mathrm{KCl}}$. The highest $\mathrm{Cu}^{2+}$ values were found in the most acidic soils. The percentage of free $\mathrm{Cu}$,

312 defined as the ratio of concentrations in $\mathrm{Cu}^{2+}$ and $\mathrm{Cu}_{\mathrm{KCl}}\left(\mathrm{fCu}^{2+}\right)$, ranged from $0.07 \%$ to $50 \%$

313 (Table S1). Our results are in agreement with Djae et al. (2017) who found $\mathrm{Cu}^{2+}$ concentrations

314 between $3.10^{-7}$ and $2 \mu \mathrm{M}$ and $\mathrm{fCu}^{2+}$ ranged from $0.01 \%$ to $44 \%$ for $\mathrm{Cu}$-contaminated soils.

315 But in moderately contaminated vineyard soils, Cornu et al. (2019) found $\mathrm{Cu}^{2+}$ of between $6 \times 10^{-}$

$316{ }^{5}-0.3 \mu \mathrm{M}$ and $\mathrm{fCu}^{2+}$ of between $0.002 \%-10 \%$. These results reveal dramatic differences

317 based on free $\mathrm{Cu}^{2+}$, even within a collection of soils with the same source of $\mathrm{Cu}$ contamination.

318 Soil pore water $\mathrm{Cu}$ has been used as a proxy for $\mathrm{Cu}$ phytotoxicity (Michaud et al. 2008),

319 assuming that few complex forms of $\mathrm{Cu}$ present in the solution play a role in $\mathrm{Cu}$ uptake by plant

320 roots. The toxicity threshold found in the literature for various plants (3.94-9.55 $\mu \mathrm{M})$ are all

321 higher than the maximum $\mathrm{Cu}_{\mathrm{KCl}}(2.64 \mu \mathrm{M})$ found in the present study (Table 2), suggesting

322 that our 18 vineyard soils do not a priori represent a risk for grapevine and also possibly maize,

323 grapevine and sunflower production (Ouzounidou 1995, Juang et al. 2012, Kolbas et al. 2014).

324 Beyond total soluble $\mathrm{Cu}$, the bioavailable form of $\mathrm{Cu}$ is generally considered to be its ionic 325 species $\mathrm{Cu}^{2+}$ (Sauvé et al. 1998), so $\mathrm{Cu}^{2+}$ concentrations would be a far more reliable tool to 326 assess $\mathrm{Cu}$ toxicity for organisms. In the present study, the $\mathrm{Cu}^{2+}$ measured in some $\mathrm{KCl}$ extracts 327 was the same as that which caused a $50 \%$ reduction $\left(\mathrm{EC}_{50}=6.3 \times 10^{-2} \mu \mathrm{M}\right)$ in root growth in 328 durum wheat (Bravin et al. 2010) (Table 2). This $\mathrm{EC}_{50}$ value was found at $2.2 \mu \mathrm{M} \mathrm{Cu}^{2+}$ for cucumber (Kader et al. 2016). To our knowledge, no such toxicity indicator assessed via ionic

$330 \mathrm{Cu}^{2+}$ has been established for grapevine. Four soils of our panel (Table S1) may be problematic 331 if converted from grapevine to widely consumed crops like wheat. Qiu et al. (2013) reported 332 that $\mathrm{Cu}^{2+}$ concentration was also an appropriate proxy to assess $\mathrm{Cu}$ toxicity for earthworms and 333 found a $\mathrm{EC}_{50}$ of $1 \mu \mathrm{M} \mathrm{Cu}^{2+}$ for Eisenia fetida mortality (Table 2). In our panel of soils, this 
suggests that one soil represents a potential toxic risk for this earthworm species (Table 2,

335 Table S1).

336 Overall, the $\mathrm{Cu}^{2+}$ and $\mathrm{Cu}_{\mathrm{KCl}}$ levels in the soils sampled in this study cannot be considered 337 completely risk-free for various organisms, and may therefore affect the sustainability of the 338 vineyards. The $\mathrm{Cu}^{2+}$ concentrations in about one-quarter of the soils were above the toxicity 339 thresholds reported in the literature and may be toxic for organisms. It is thus important to 340 examine and understand the factors that control $\mathrm{Cu}$ availability and potential toxicity.

\subsection{Diversity of soils in terms of DOM properties}

343 We calculated several spectroscopic indices to assess DOM quality (Fig. S4). SUVA254 values 344 varied between 5 and $61 \mathrm{~L} \mathrm{~g} \mathrm{C}^{-1} \mathrm{~cm}^{-1}$ (Fig. 1, Table S1). This range is similar to that reported 345 in other studies on agricultural soils: 6-65 $\mathrm{L} \mathrm{g} \mathrm{C}^{-1} \mathrm{~cm}^{-1}$ (Amery et al. 2007); 27-46 $\mathrm{L} \mathrm{g} \mathrm{C}^{-1} \mathrm{~cm}^{-}$ $346{ }^{1}$ (Amery et al. 2008); 8-58 $\mathrm{L} \mathrm{g} \mathrm{C}^{-1} \mathrm{~cm}^{-1}$ (Supriatin et al. 2015). DOM is considered to be more 347 aromatic when the $\mathrm{SUVA}_{254}$ index is higher (Weishaar et al. 2003). It has been reported that 348 SUVA $_{254}$ values below $30 \mathrm{~L} \mathrm{~g} \mathrm{C}^{-1} \mathrm{~cm}^{-1}$ suggest that DOM is composed mainly of hydrophilic 349 substances (Yeh et al. 2014), which is the case of about $80 \%$ of our samples. SR values varied 350 three-fold between 0.42 and 1.28 (Fig. 1, Table S1), which is the same range as those reported 351 by Tang et al. (2019) for Chinese agricultural soils (0.36-1.7). The $\mathrm{S}_{\mathrm{R}}$ index is inversely related 352 to molecular size, high $S_{R}$ values indicate low molecular weight DOM (Helms et al. 2008) while 353 low $\mathrm{S}_{\mathrm{R}}$ values indicate high molecular weight and highly condensed organic molecules (Gao et 354 al. 2017).

355 Fluorescence EEM spectra (Fig. S4) were acquired to describe heterogeneities in DOM in the 356 samples more precisely by calculating indices such as FI, HIX and BIX. The FI values ranged 357 from 1.10 to 1.34 (median 1.22) (Fig. 1, Table S1). FI values are usually used to distinguish 
sources of DOM. McKnight et al. (2001) found that low FI values ( 1.3) correspond to higher plant-derived molecules, while high values ( 1.9) indicate microbial or microbially-processed DOM. This suggests that the majority of DOM collected from our samples originated from vascular plants, and that microbial contributions were limited. The BIX index is used to assess the relative production of recent DOM and usually ranges from 0.5 to 1 . In the present study, about $75 \%$ of the samples had BIX between 0.6 and 0.7 , indicating a relatively low contribution of fresh autochthonous DOM substances (Table S1), while the other $25 \%$ had BIX between 0.7 and 0.9, suggesting fresh DOM production by organisms (Huguet et al. 2009; He et al. 2016). In our samples the HIX values were contrasted, with almost 10 -fold variation from 1.31 to 10.33 (median 5.75) (Fig. 1, Table S1). Two of the soils (D and L) were characterised by very low HIX values (Table S1) due to the presence of tyrosine-like fluorescence at an excitation wavelength of 240-260 nm and emission of 300-340 nm (Fig. S4a). This tyrosinelike fluorescence band was absent from all other EEM spectra that were similar to that of soil B (Fig. S4b). HIX stands for degree of humification or condensation of DOM (Zsolnay et al. 1999), but has also been used to characterise DOM aromaticity (Ohno et al. 2007). Our HIX results are in the same range as those reported by Daouk et al. (2015) for Swiss vineyard soils (0.1-7.0) and as those reported by Tang et al. (2019) (2 to 10). However, HIX values varying from 10 to 30 have been reported in several arable soils (Kalbitz et al. 2003). Compared to the latter range, our soils had low HIX values and can be characterized as weakly-humified.

\subsection{Relationships between the variables}

We performed a principal component analysis (PCA) of all 18 soil extracts to describe the relationships between the solution variables and to identify homogeneous groups. $64 \%$ of total variance is explained by the first two principal components (Fig. 2a). The first principal component revealed $44.5 \%$ variance of data and was positively associated with $\mathrm{Cu}_{\mathrm{KCl}}, \mathrm{Cu}^{2+}$, Fe concentrations, and $\mathrm{SUVA}_{254}$, and was negatively associated with $\mathrm{pH}_{\text {water, }} \mathrm{pH}_{\mathrm{KCl}}$ and $\mathrm{HIX}$. 
383

384

The second principal component explained $19.2 \%$ of variance and was positively associated with $\mathrm{C}_{\text {org }}$, the $\mathrm{C}: \mathrm{N}$ ratio, and negatively associated with FI and BIX. Two groups can be distinguished on the principal plan plot (Fig. 2b): group 1 is composed of the eight most alkaline soils $\left(7.8<\mathrm{pH}_{\text {water }}<8.3\right)$, whiles group 2 is composed of the 10 most acidic soils $\left(6.3<\mathrm{pH}_{\text {water }}\right.$ $<7.5)$. The differences between the groups are mainly explained by the $\mathrm{pH}_{\mathrm{water}}$ values (PCA correlation coefficient with Component 1: -0.92 ; with Component 2: 0.03). On the first axis, the soils in group 1 share high values of $\mathrm{pH}$ and $\mathrm{HIX}$, and low values of $\mathrm{Cu}_{\mathrm{KCl}}, \mathrm{Fe}$, and $\mathrm{Cu}^{2+}$. The opposite trend was observed in group 2. On the second axis, soils in group 2 have more contrasted FI and BIX than those in group 1. Indeed, in group 1, FI values ranged from 1.20 to 1.31; and BIX values from 0.67 to 0.75 . Comparatively, these indices show a larger range in group 2, with 1.10 - 1.34 for FI and 0.59 - 0.86 for BIX. Group 1 is composed of alkaline soils with low $\mathrm{Cu}$ concentrations in solution and relatively highly-humified DOM, while group 2 is composed of more acidic soils with high concentrations of $\mathrm{Cu}_{\mathrm{KCl}}$ and $\mathrm{Cu}^{2+}$, and contrasted contributions of microbial DOM.

Pearson's correlation coefficients were analysed to describe the links between the variables measured in the soils and in the extracts (Fig. 3). $\mathrm{pH}_{\mathrm{water}}$ and $\mathrm{pH}_{\mathrm{KCl}}$ were strongly and positively correlated $(\mathrm{r}=0.94, \mathrm{p}<0.01)$. Total dissolved $\mathrm{Fe}$ and $\mathrm{Cu}$ concentrations were negatively correlated with $\mathrm{pH}$ (Fig. 3), with $\mathrm{r}=0.77,0.73(\mathrm{p}<0.01)$, respectively. Fig. 4a reports total $\mathrm{Cu}$ in extracts as a function of total $\mathrm{Cu}$ in the soils. We found no immediate relationship between $\mathrm{Cu}$ availability and the level of contamination. $\mathrm{Cu}$ KCl concentrations globally increased with decreasing soil pH (Fig. 4b). This result confirms the fact that metals are more soluble in acidic soils, as reported by McBride et al. (1997). None of the $\mathrm{Fe}$ and $\mathrm{Cu}$ concentrations were significantly correlated with DOC (Fig. 3). $\mathrm{Cu}^{2+}$ was strongly linked to $\mathrm{Cu}_{\mathrm{KCl}}(\mathrm{r}=0.82, \mathrm{p}<0.01)$ (Fig. 3, Fig. 4c), showing that $\mathrm{Cu}$ solubilisation affects its concentration of free ions. A slightly positive relationship was found between $\mathrm{pH}_{\mathrm{KCl}}$ and HIX (Fig. 3), suggesting that the most 
408 humified DOM was present in the most alkaline samples, as confirmed by the results of the 409 PCA.

$410 \mathrm{Cu}^{2+}$ concentrations and $\mathrm{fCu}^{2+}$ were strongly linked to the $\mathrm{pH}$ of the extracts, with correlation 411 coefficients of -0.94 and -0.91 respectively (Fig. 3, Fig. 4d), suggesting that $\mathrm{Cu}^{2+}$ decreased 412 with increasing $\mathrm{pH}$. The strong relationship between $\mathrm{pH}$ and $\mathrm{Cu}^{2+}$ has already been reported 413 (McBride and Blasiak 1979, Sauvé et al. 1995, Laurent et al. 2020), confirming that pH is the 414 main factor controlling $\mathrm{Cu}$ speciation in solution. When $\mathrm{pH}$ increases, DOM is more negatively 415 charged due to the deprotonation of its functional groups. This promotes its complexation with $416 \mathrm{Cu}$, leading to a drastic decrease in $\mathrm{Cu}^{2+}$ activity in solution (Bravin et al. 2009; Ren et al. 2015). 417 Conversely, at low $\mathrm{pH}$, competition for DOM binding sites is high between $\mathrm{Cu}^{2+}$ and $\mathrm{H}^{+}$, which 418 promotes increasing $\mathrm{Cu}^{2+}$ activity. A pH above 6.5 seems to be the safety threshold for the soils in our collection in terms of $\mathrm{Cu}$ toxicity when $\mathrm{Cu}^{2+}$ is used as a proxy $(\mathbf{F i g} . \mathbf{4 d})$.

420 No tangible relationship was found between $\mathrm{C}_{\text {org }}$ values and DOC concentrations in the extracts 421 (Fig. 3), meaning that the solubilisation rates of $\mathrm{C}_{\text {org }}$ may differ with the soil conditions or 422 properties. None of DOM optical indices was significantly linked to DOC concentrations in the $423 \mathrm{KCl}$ extracts, indicating that DOM quality was not related to the quantity of DOM in solution. 424 No significant relationship was found between the $\mathrm{S}_{\mathrm{R}}$ and the SUVA 254 indices. SUVA 254 and 425 HIX indices were negatively linked in this study $(r=-0.71, p<0.01)$ (Fig. 3). This negative 426 relationship is all the more surprising as these indices are both related to DOM aromaticity. In 427 the literature, SUVA 254 and HIX are generally positively correlated (He et al. 2016; Tang et al. 428 2019). However, such unexpected differences between these two indices have already been 429 observed (Inamdar et al. 2011; Broder et al. 2017). Considering the differences in pH between 430 soils, and given that fluorescence is $\mathrm{pH}$-dependent, one may wonder if the variations observed 431 in these two indices are not affected by the effect of $\mathrm{pH}$ on spectroscopic analyses. However, 432 an impact on fluorescence analyses is unlikely in our range of soil $\mathrm{pH}$, and would, in any case, 
433 be less than differences due to the sources and composition of DOM (Hudson et al. 2007). The

434 presence of protein-like fluorescence was observed in EEM spectra of only two soils (D and L)

435 and cannot explain the negative correlation between HIX and SUVA 254 . Moreover, it has been

436 reported that $\mathrm{SUVA}_{254}$ measurements may be subject to some bias since Fe, colloids, and other

437 constituents also absorb at $254 \mathrm{~nm}$ (Weishaar et al. 2003; Yang and Hur 2014). Since there were

438 huge differences in Fe concentrations among our samples (i.e., varying by a factor of 12, Table

439 S1), the SUVA 254 results in this study should be interpreted with caution. In a collection of 440 samples with such contrasted concentrations of dissolved Fe as those measured in the present

441 study, it would therefore not be appropriate to use the SUVA $_{254}$ index to assess DOM 442 aromaticity, and HIX appears to be a more reliable tool for that purpose. No significant 443 relationship was found between HIX and $S_{R}$, suggesting that, in our soil extracts, DOM 444 condensation may not be directly related to its molecular size. Moreover, the negative 445 correlation between HIX and BIX $($ Fig. $4 \mathbf{b})(\mathrm{r}=-0.82, \mathrm{p}<0.01)$ indicates that the most aromatic 446 DOM is associated with older molecules derived from higher plants (Tang et al. 2019), which 447 is quite consistent. No significant link was found between HIX and FI. Nevertheless, the 448 positive relationship between BIX and FI $(\mathrm{r}=0.63, \mathrm{p}<0.01)$ was not surprising and suggested 449 that the soils with DOM originating from a microbial source were related to the highest 450 autochthonous contributions, as reported in other works (Tang et al. 2019; Musadji et al. 2020).

451 Overall, these results indicate that the 18 soils sampled in our study differed in DOM quality 452 even though they had similar concentrations of DOC. Given the significant affinity of Cu for 453 DOM, these differences in DOM quality are expected to affect the geochemistry of $\mathrm{Cu}$ in 454 solution.

\subsection{Prediction of $\mathrm{Cu}$ availability using the properties of the soils and the extracts}

456 The risk of $\mathrm{Cu}$ environmental toxicity could be better assessed if its availability could be 457 predicted using the variables measured in the soil and in the soil solution. However, organisms 
often use mechanisms to resist the stress caused by $\mathrm{Cu}$ toxicity. For instance, some plants take up and sequestrate $\mathrm{Cu}$ in cells where it cannot cause harm (Küpper et al. 2009). Nevertheless, as $\mathrm{Cu}$ environmental availability is linked to its total $\left(\mathrm{Cu}_{\mathrm{KCl}}\right)$ and ionic $\left(\mathrm{Cu}^{2+}\right)$ concentrations in soil solutions, predicting these concentrations could enable more accurate evaluation of potential $\mathrm{Cu}$ toxicity to a certain extent (see Section 3.2). Table 3 shows the best models calculated to predict $\mathrm{Cu}_{\mathrm{KCl}}$ and $\mathrm{Cu}^{2+}$ among the 18 vineyard soils sampled in this study.

\subsubsection{Prediction of total $\mathrm{Cu}$ in extracts $\mathrm{CuKCl}$}

Among the one-variable models tested to predict $\mathrm{Cu}_{\mathrm{KCl}}$, the model with $\mathrm{pH}_{\text {water }}$ (a) showed the best goodness of fit $\left(\mathrm{R}^{2}\right.$ adj $=0.575$, Table 3). This suggests that $\mathrm{pH}$ is the main factor driving $\mathrm{Cu}$ solubilisation in the soils sampled in this study. However, this model showed marked dispersion of points around the 1:1 line (Fig. 5a), more visible in soils in group 1 than in soils in group 2. The prediction was better when $\mathrm{Cu}_{\mathrm{T}}$ was added to $\mathrm{pH}$ (model (b)), the $\mathrm{R}^{2}$ adj value raised to 0.71 and the RMSE decreased from 0.28 to 0.23 (Table 3). The points were then less dispersed than with the preceding model, except in soils in group 2 (Fig. 5b). The respective coefficients of $\mathrm{pH}$ and $\mathrm{Cu}_{\mathrm{T}}$ are suitable for the presumed mechanisms. Indeed, it has been reported that metal desorption increases with a decrease in $\mathrm{pH}$, which is why metals tend to be more soluble in acidic environments (McBride and Blasiak 1979; Degryse et al. 2009). Moreover, at higher $\mathrm{pH}, \mathrm{Cu}$ oxyhydroxides or carbonates may form and precipitate thereby reducing the $\mathrm{Cu}$ in solution (McBride 1989). As expected, the model showed that the higher the $\mathrm{Cu}_{\mathrm{T}}$, the higher the concentration of soluble $\mathrm{Cu}$ in solution $\left(\mathrm{Cu} \mathrm{KCl}_{1}\right)$. Sauvé et al. (1997) underlined the importance of $\mathrm{pH}$ and $\mathrm{Cu}_{\mathrm{T}}$ in $\mathrm{Cu}$ solubilisation, but in the reverse hierarchy. These authors found that in 66 soils with diverse sources of $\mathrm{Cu}$ contamination, $90 \%$ of variation in soluble $\mathrm{Cu}$ was explained by total $\mathrm{Cu}$ in the soils and the importance of $\mathrm{pH}$ was minimal. 
482 This could be explained by the wider range of $\mathrm{Cu}_{\mathrm{T}}$ in their study (14-3000 mg kg $\mathrm{kg}^{-1}$ ) which 483 reinforced the contribution of $\mathrm{Cu}_{\mathrm{T}}$ in predicting soluble $\mathrm{Cu}$.

484 The concentration of DOC did not appear in the best models, presumably because of its limited 485 variability in our initial dataset. However, $\mathrm{Cu}_{\mathrm{KCl}}$ predictability was dramatically improved when 486 DOM quality parameters were added as predictors in addition to $\mathrm{pH}$ and $\mathrm{Cu}_{\mathrm{T}}$. This suggests that 487 in the present study, $\mathrm{Cu}$ availability depended more on DOM characteristics than on its concentration. Among all the DOM indices tested in the regressions, only HIX and FI emerged significantly, and the best prediction was obtained by equation (c) (Table 3, Fig. 5c), which explained $83.2 \%$ of variance, showing good accuracy of this model for the prediction of $\mathrm{Cu}_{\mathrm{KCl}}$.

491 Compared to model (b), model (c) produced lower RMSE (0.17) and a slope closer to $1(0.85)$

492 (Fig. 5c). The contributions of $\mathrm{pH}_{\text {water, }} \mathrm{Cu}_{\mathrm{T}}$, FI and HIX were all significant in the model $(\mathrm{p}<$ 493 0.001) (Table 3). The variance inflation factor (VIF) did not identify correlations between the predictors (VIF < 2.3). HIX and FI were both expressed with negative coefficients in the model, suggesting that the solubilisation of $\mathrm{Cu}$ is enhanced with lowly-condensed plant-derived DOM molecules. This suggests that, in the vineyard soils studied here, molecules with low aromaticity have the most affinity for $\mathrm{Cu}$ for its solubilisation. This finding contradicts previous studies suggesting that the most aromatic DOM had higher affinity for $\mathrm{Cu}$ and promoted its solubilisation through complexation (Amery et al. 2007; Amery et al. 2008; Araújo et al. 2019). In the present study, DOM composed of more hydrophilic molecules may have higher $\mathrm{Cu}$ 501 binding capacity because of its higher proportion of O-containing functional groups (hydroxyl, 502 carboxylic acid, sulfonic acid and amine) than aromatic and hydrophobic substances (Baham et 503 al. 1978; Leenheer 1981). Moreover, the negative coefficient of FI in the model suggests a higher plant origin for the DOM components that bind $\mathrm{Cu}$. Our results are consistent with those of He et al. (2016), who found higher concentrations of heavy metals in sediment solutions with lower aromatic DOM molecules, which the authors linked to amino acids. Moreover, it has 
previously been reported that the ability of DOM hydrophilic and low aromatic components to transport $\mathrm{Cu}$ is greater than that of hydrophobic molecules (Han and Thompson 1999; 2003). These authors explained that low aromatic and hydrophilic molecules were more mobile, while aromatic and complex components tended to be adsorbed on soil particles.

\subsubsection{Prediction of free ionic $\mathrm{Cu}^{2+}$}

Among the models with just one predictor, the one with $\mathrm{pH}_{\mathrm{KCl}}$ (model (d)) appeared to be the most effective and explained $88.3 \%$ of $\mathrm{Cu}^{2+}$ variance (Table 3). The RMSE value was low (0.4), implying good accuracy of the prediction (Fig. 5d). The high $\mathrm{R}^{2}$ adj $(0.88)$ of model (d) highlights the importance of $\mathrm{pH}$ in predicting $\mathrm{Cu}^{2+}$ concentrations.

We hypothesised that free $\mathrm{Cu}^{2+}$ may be linked to the solubility of $\mathrm{Cu}$, as we found a positive relationship between $\mathrm{Cu}^{2+}$ and $\mathrm{Cu}_{\mathrm{KCl}}$ (Fig. 4c). When adding $\mathrm{Cu}_{\mathrm{KCl}}$ to $\mathrm{pH} \mathrm{KCl}_{\text {a }}$ as predictors of $\mathrm{Cu}^{2+}$ (model (e)), the $\mathrm{R}^{2}$ adj increased from 0.88 to 0.91 . This slight improvement can be observed in Fig. 5e. The corresponding VIF was the maximum receivable (2.3), certainly due to the relative effect of $\mathrm{pH}$ on $\mathrm{Cu}$ solubilisation. The contributions of $\mathrm{pH}_{\mathrm{KCl}}$ and $\mathrm{Cu}_{\mathrm{KCl}}$ were all significant $(\mathrm{p}<0.001)$ in explaining $\mathrm{Cu}^{2+}$ variability. The coefficients in the model suggest that

$\mathrm{Cu}^{2+}$ increases with $\mathrm{Cu}_{\mathrm{KCl}}$, and decreasing $\mathrm{pH}$. Compared to model (d), model (e) was more accurate with a lower RMSE (0.34 instead of 0.4) (Table 3).

BIX was the DOM index that appeared in the best three-variables model (model (f), Table 3). Models with more than three variables did not present any statistical improvement (data not shown). In model (f), adding $\mathrm{BIX}$ to $\mathrm{pH}_{\mathrm{KCl}}$ and $\mathrm{Cu}_{\mathrm{KCl}}$ did not enhance the effectiveness of the prediction compared to model (e) (Fig. 5f), with similar R $^{2}$ adj and RMSE (0.92 and 0.32 respectively) (Table 3). Even though the contribution of BIX to the model was significant ( $\mathrm{p}<$ 0.05), the addition of BIX was not needed to explain the variability of our collection of samples. Moreover, the max VIF of model (f) (2.44) was higher than the fixed threshold of 2.3, 
531 illustrating multicollinearity between the predictors that probably weakens the stability of the

532 prediction. Taken together, these results suggest that including DOM indices does not improve 533 the modelling of $\mathrm{Cu}^{2+}$ and that only $\mathrm{pH}_{\mathrm{KCl}}$ and $\mathrm{Cu}_{\mathrm{KCl}}$ were needed.

534 In the literature, $\mathrm{pH}$ is widely reported to play an important role explaining free ionic $\mathrm{Cu}^{2+}$ 535 activities and the log-log relationship between these two variables is usually linear (McBride 536 and Blasiak 1979; Sauvé et al. 1995; McBride et al. 1997; Sauvé et al. 1997; Bravin et al. 2009). 537 Sauvé et al. (1997) proposed the following equation to predict $\mathrm{Cu}^{2+}$ activity in $\mathrm{CaCl}_{2}$ extracts 538 of a collection of wide $\mathrm{Cu}$-contaminated soils: $\mathrm{pCu}=-1.7 \log _{10} \mathrm{Cu}_{\mathrm{T}}+1.4 \mathrm{pH}+3.4$. In contrast 539 to our study, the OM parameters (concentrations and quality) were not included in the model 540 calculations and the authors underlined the importance of the degree of $\mathrm{Cu}$ contamination in 541 predicting $\mathrm{Cu}^{2+}$. However, interestingly, the $\mathrm{pH}$ coefficient in our study (model (e)) is consistent with the results of McBride (1989) who reported that slopes for $\log \mathrm{Cu}^{2+}-\mathrm{pH}$ plots are generally

543 lower than 2. This suggests that $\mathrm{pH}$ plays a constant role in $\mathrm{Cu}^{2+}$ prediction. But the optical 544 parameters describing the quality of DOM in soil solutions were of no use in explaining the 545 concentrations of $\mathrm{Cu}^{2+}$.

\subsection{Influence of DOC composition on $\mathrm{Cu}$ speciation}

547 We calculated $\mathrm{Cu}$ speciation in solution based on thermodynamic models and on several 548 hypotheses concerning DOM composition. We found that considering DOM as $100 \%$ HA led 549 to underprediction of free $\mathrm{Cu}^{2+}$ compared to experimental observations in all samples (Fig. S5). 550 Considering all DOM as FA produced better results, but even using only $65 \%$ of active DOM 551 as FA (a widespread assumption in similar studies) resulted in marked discrepancies between 552 model and experimental results. This observation - made here using the NICA-Donnan model 553 to describe ion binding to DOM - is in agreement with previous estimations made using the 554 Windermere humic aqueous model (WHAM) on a large set of soil solutions (Djae et al. 2017). 
555 For the model results to fit the experimental observations, the percentage of active DOM, 556 rDOM, was adjusted separately for each sample. The values of rDOM obtained ranged between 5570.10 and 1.68 , reflecting the wide variability of the active pool within DOM. This is consistent 558 with the physically meaningful range of 35-215\% estimated by Djae et al. (2017). The 559 variations in rDOM were compared to the variations in the chemical and optical parameters, 560 but no multilinear regression model could be established (data not shown).

561 The amount of $\mathrm{Cu}$ bound to carboxylic or phenolic groups of DOM can be estimated using 562 thermodynamic modelling. Results show that binding to phenolic groups becomes predominant above pH 7.4 (Fig. S6). This suggests that these DOM binding groups, deprotonated at alkaline $\mathrm{pH}$, have a very high affinity for $\mathrm{Cu}$. Thus, in alkaline soils, the nature of DOM binding sites will be important in controlling $\mathrm{Cu}$ speciation.

\section{Conclusions}

The main goal of this work was to assess the contribution of DOM spectroscopic indices to predicting two $\mathrm{Cu}$ availability proxies in 18 organic vineyard soils. Our results showed that in the $\mathrm{KCl}$ extracts, the total concentration of $\mathrm{Cu}$ varied 23 -fold while that of free ionic $\mathrm{Cu}^{2+}$ varied 4,600-fold among soils, pointing to wide diversity of soils in terms of $\mathrm{Cu}$ availability. Four soils had concentrations of $\mathrm{Cu}^{2+}$ higher than the toxicity levels for organisms reported in the

573 literature. These samples were considered as potentially harmful for vineyard soil organisms.

574 Our results also showed that $\mathrm{Cu}$ environmental availability was weakly related to the level of

$575 \mathrm{Cu}$ contamination in the soils. $\mathrm{pH}$ was the main factor controlling $\mathrm{Cu}$ environmental 576 availability, as it was closely and positively correlated with the concentrations of total $\mathrm{Cu}$ and 577 free ionic $\mathrm{Cu}^{2+}$ measured in $\mathrm{KCl}$ extracts. Thus, in theory, toxicity problems can occur even in 578 moderately $\mathrm{Cu}$-contaminated soils when the soils are particularly acidic. It would thus be safer to maintain the $\mathrm{pH}$ above 6.5 . To this end, liming is possible but should be applied with caution, 
so as not to jeopardise plant uptake of other nutrients like Fe, whose availability is low at

581 alkaline $\mathrm{pH}$.

582 This work highlighted the fact that even though the DOC concentrations were similar among 583 the soils, noticeable differences were found in DOM quality, as assessed by optical 584 spectroscopy. Absorbance and fluorescence analyses are thus appropriate to identify these 585 differences in chromophoric and fluorescent DOM in soils.

586 The prediction of total $\mathrm{Cu}$ in $\mathrm{KCl}$ extracts was clearly improved when $\mathrm{DOM}$ spectral indices 587 (HIX and FI) were taken into account, in addition to $\mathrm{pH}$ and $\mathrm{Cu}_{\mathrm{T}}$. This study thus emphasizes 588 that the quality of DOM affects the availability of $\mathrm{Cu}$ in the soil more than its quantity. Although 589 this finding now needs to be tested on a wider dataset (with different sources of contamination), 590 it suggests that organic management in $\mathrm{Cu}$-contaminated vineyards needs to be redesigned, to 591 better control quality of dissolved organic matter production as a function of the nature of 592 organic matter amendments.

\section{Declarations}

595 Ethics approval and consent to participate

596 Not applicable

\section{Consent for publication}

$598 \quad$ Not applicable

\section{$599 \quad$ Availability of data and materials}

600 All data generated or analysed during this study are included in this published article and its 601 supplementary information files.

\section{Competing interests}


603 The authors declare that they have no competing interests.

\section{Funding}

605 This work was financially supported by the CNRS-INSU EC2CO program under the 606 'INTRIGUE' project, by Bordeaux Sciences Agro Institute of Agricultural Sciences through 607 the PhD scholarship of Frédéric Ouedraogo and by the French National Institute for Agriculture, 608 Food and Environment (INRAE).

\section{Authors' contributions}

610 Frédéric Ouedraogo: Conceptualization, Investigation, Formal analysis, Writing-original draft

611 Jean-Yves Cornu: Supervision, Writing-original draft

612 Noémie Janot: Formal analysis, Supervision, Writing-review \& editing

613 Christophe Nguyen: Formal analysis, Writing-review \& editing

614 Mahaut Sourzac: Investigation

615 Edith Parlanti: Conceptualization, Funding acquisition, Supervision, Writing-original draft

616 Laurence Denaix: Conceptualization, Funding acquisition, Supervision, Writing-original draft 617 All authors read and approved the final manuscript.

618

\section{Acknowledgments}

620 The authors wish to thank Thierry Robert for help in soil sampling, Sylvie Bussière for

621 determining the DOC concentration in soil extracts, Cécile Coriou for technical and human 622 support in ICP-OES measurements and Sylvie Millin for $\mathrm{C}_{\text {org }}$ and $\mathrm{N}$ determinations. The authors 623 would also like to thank Dario Omanović for his assistance in adapting the TreatEEM program 624 and Nicolas Fanin for his support throughout the $\mathrm{PhD}$ research of Frédéric Ouedraogo. 


\section{References}

626 Amery F, Degryse F, Cheyns K, De Troyer I, Mertens J, Merckx R, Smolders E (2008) The UV-absorbance of dissolved organic matter predicts the fivefold variation in its affinity for mobilizing $\mathrm{Cu}$ in an agricultural soil horizon. European Journal of Soil Science 59(6):1087-1095. https://doi.org/10.1111/j.1365-2389.2008.01078.x

630

Amery F, Degryse F, Degeling W, Smolders E, Merckx R (2007) The Copper-MobilizingPotential of Dissolved Organic Matter in Soils Varies 10-Fold Depending on Soil Incubation and Extraction Procedures. Environmental Science \& Technology 41(7):2277-2281. https://doi.org/10.1021/es062166r

Andrivon D, Bardin M, Bertrand C, Brun L, Daire X, Fabre F, Gary C, Montarry J, Nicot P, Reignault P, Tamm L, Savini I (2018) Can organic agriculture give up copper as a crop protection product? Synthesis of the scientific assessment report. Institut national de la recherche agronomique (INRA) :68. https://doi.org/hal-02944872

Araújo E, Strawn DG, Morra M, Moore A, Ferracciú Alleoni LR (2019) Association between extracted copper and dissolved organic matter in dairy-manure amended soils. Environmental Pollution 246:1020-1026. https://doi.org/10.1016/j.envpol.2018.12.070

Baham J, Ball NB, Sposito G (1978) Gel Filtration Studies of Trace Metal-Fulvic Acid Solutions Extracted From Sewage Sludges. Journal of Environmental Quality 7(2):181188. https://doi.org/10.2134/jeq1978.00472425000700020006x

Baken S, Degryse F, Verheyen L, Merckx R, Smolders E (2011) Metal Complexation Properties of Freshwater Dissolved Organic Matter Are Explained by Its Aromaticity and by Anthropogenic Ligands. Environ Sci Technol 45(7):2584-2590. https://doi.org/10.1021/es103532a 
648 Ballabio C, Panagos P, Lugato E, Huang J-H, Orgiazzi A, Jones A, Fernández-Ugalde O,

649

650

651

652

653

654

655

656

657

658

659

660

661

662

663

664

665

666

667

668

669 Borrelli P, Montanarella L (2018) Copper distribution in European topsoils: An assessment based on LUCAS soil survey. Science of The Total Environment 636:282298. https://doi.org/10.1016/j.scitotenv.2018.04.268

Bravin MN, Le Merrer B, Denaix L, Schneider A, Hinsinger P (2010) Copper uptake kinetics in hydroponically-grown durum wheat (Triticum turgidum durum L.) as compared with soil's ability to supply copper. Plant Soil 331(1-2):91-104. https://doi.org/10.1007/s11104-009-0235-3

Bravin MN, Martí AL, Clairotte M, Hinsinger P (2009) Rhizosphere alkalisation — a major driver of copper bioavailability over a broad $\mathrm{pH}$ range in an acidic, copper-contaminated soil. Plant Soil 318(1):257-268. https://doi.org/10.1007/s11104-008-9835-6

Broder T, Knorr K-H, Biester H (2017) Changes in dissolved organic matter quality in a peatland and forest headwater stream as a function of seasonality and hydrologic conditions. Hydrology and Earth System Sciences 21(4):2035-2051. https://doi.org/10.5194/hess-21-2035-2017

Brun LA, Maillet J, Hinsinger P, Pépin M (2001) Evaluation of copper availability to plants in copper-contaminated vineyard soils. Environmental Pollution 111(2):293-302. https://doi.org/10.1016/S0269-7491(00)00067-1

Chaignon V, Sanchez-Neira I, Herrmann P, Jaillard B, Hinsinger P (2003) Copper bioavailability and extractability as related to chemical properties of contaminated soils from a vine-growing area. Environmental Pollution 123(2):229-238. https://doi.org/10.1016/S0269-7491(02)00374-3 
670 Coll P, Le Cadre E, Blanchart E, Hinsinger P, Villenave C (2011) Organic viticulture and soil

671

672

673

674

675

676

677

678

679

680

681

682

683

684

685

686

687

688

689

690

691

692 quality: A long-term study in Southern France. Applied Soil Ecology :S0929139311001570. https://doi.org/10.1016/j.apsoil.2011.07.013

Cornu JY, Denaix L, Schneider A, Pellerin S (2007) Temporal evolution of redox processes and free $\mathrm{Cd}$ dynamics in a metal-contaminated soil after rewetting. Chemosphere 70(2):306-314. https://doi.org/10.1016/j.chemosphere.2007.06.003

Cornu JY, Randriamamonjy S, Gutierrez M, Rocco K, Gaudin P, Ouerdane L, Lebeau T (2019) Copper phytoavailability in vineyard topsoils as affected by pyoverdine supply. Chemosphere 236:124347. https://doi.org/10.1016/j.chemosphere.2019.124347

Cory R, Mcknight D (2005) Fluorescence Spectroscopy Reveals Ubiquitous Presence of Oxidized and Reduced Quinones in Dissolved Organic Matter. Environmental science \& technology 39:8142-9. https://doi.org/10.1021/es0506962

Daouk S, Frege C, Blanc N, Mounier S, Redon R, Merdy P, Lucas Y, Pfeifer H-R (2015) Fluorescence spectroscopy to study dissolved organic matter interactions with agrochemicals applied in Swiss vineyards. Environ Sci Pollut Res 22(12):9284-9292. https://doi.org/10.1007/s11356-015-4086-6

Degryse F, Smolders E, Parker DR (2009) Partitioning of metals (Cd, Co, Cu, Ni, Pb, Zn) in soils: concepts, methodologies, prediction and applications - a review. European Journal of Soil Science 60(4):590-612. https://doi.org/10.1111/j.13652389.2009.01142.x

Derrien M, Yang L, Hur J (2017) Lipid biomarkers and spectroscopic indices for identifying organic matter sources in aquatic environments: A review. Water Research 112:58-71. https://doi.org/10.1016/j.watres.2017.01.023 
693 Djae T, Bravin MN, Garnier C, Doelsch E (2017) Parameterizing the binding properties of 694 dissolved organic matter with default values skews the prediction of copper solution

El Hadri H, Chéry P, Jalabert S, Lee A, Potin-Gautier M, Lespes G (2012) Assessment of speciation and ecotoxicity in soil: Heterogeneity in reactive DOM impacts soil $\mathrm{Cu}$ ecotoxicity. Environmental Toxicology and Chemistry 36(4):898-905. https://doi.org/10.1002/etc.3622

702

703

704

705

706

707

708

709

710

711

712

713

714

715

716 diffuse contamination of agricultural soil by copper in Aquitaine region by using French national databases. Science of The Total Environment 441:239-247. https://doi.org/10.1016/j.scitotenv.2012.09.070

European Food Safety Authority (EFSA), Arena M, Auteri D, Barmaz S, Bellisai G, Brancato A, Brocca D, Bura L, Byers H, Chiusolo A, Court Marques D, Crivellente F, De Lentdecker C, Egsmose M, Erdos Z, Fait G, Ferreira L, Goumenou M, Greco L, Ippolito A, Istace F, Jarrah S, Kardassi D, Leuschner R, Lythgo C, Magrans JO, Medina P, Miron I, Molnar T, Nougadere A, Padovani L, Parra Morte JM, Pedersen R, Reich H, Sacchi A, Santos M, Serafimova R, Sharp R, Stanek A, Streissl F, Sturma J, Szentes C, Tarazona J, Terron A, Theobald A, Vagenende B, Verani A, Villamar-Bouza L (2018) Peer review of the pesticide risk assessment of the active substance copper compounds copper(I), copper(II) variants namely copper hydroxide, copper oxychloride, tribasic copper sulfate, copper(I) oxide, Bordeaux mixture. EFSA Journal 16(1). https://doi.org/10.2903/j.efsa.2018.5152

Fernández-Calviño D, Nóvoa-Muñoz JC, Díaz-Raviña M, Arias-Estévez M (2009) Copper accumulation and fractionation in vineyard soils from temperate humid zone (NW Iberian Peninsula).

Geoderma 153(1-2):119-129. https://doi.org/10.1016/j.geoderma.2009.07.024 
Fernández-Calviño D, Soler-Rovira P, Polo A, Díaz-Raviña M, Arias-Estévez M, Plaza C (2010) Enzyme activities in vineyard soils long-term treated with copper-based fungicides. Soil Biology and Biochemistry 42(12):2119-2127. https://doi.org/10.1016/j.soilbio.2010.08.007

Ferreira PAA, Marchezan C, Ceretta CA, Tarouco CP, Lourenzi CR, Silva LS, Soriani HH, Nicoloso FT, Cesco S, Mimmo T, Brunetto G (2018) Soil amendment as a strategy for the growth of young vines when replanting vineyards in soils with high copper content. Plant Physiology and Biochemistry $126: 152-162$. https://doi.org/10.1016/j.plaphy.2018.03.003

Flores-Álvarez JM, González I, García-de la Rosa LA, Mancilla-Peña F, Reyes-Gómez J (2011) Carbon paste electrodes modified with biosolids, soils and biocomposites utilized to study the interaction between organic matter and copper. Journal of Environmental Management 92(3):448-456. https://doi.org/10.1016/j.jenvman.2010.08.033

Fox J, Weisberg S (2019) An R companion to applied regression, Third Edition. Sage Publications

Fuentes M, Olaetxea M, Baigorri R, Zamarreño AM, Etienne P, Laîné P, Ourry A, Yvin J-C, Garcia-Mina JM (2013) Main binding sites involved in $\mathrm{Fe}(\mathrm{III})$ and $\mathrm{Cu}(\mathrm{II})$ complexation in humic-based structures. Journal of Geochemical Exploration 129:14-17. https://doi.org/10.1016/j.gexplo.2012.12.015

Gonzaga MIS, Matias MI de AS, Andrade KR, Jesus AN de, Cunha G da C, Andrade RS de, Santos JC de J (2020) Aged biochar changed copper availability and distribution among soil fractions and influenced corn seed germination in a copper-contaminated soil. Chemosphere 240:124828. https://doi.org/10.1016/j.chemosphere.2019.124828 
740 Guo X, Zhu N, Chen L, Yuan D, He L (2015) Characterizing the fluorescent properties and

741

742

743

744

745

746

747

748

749

750

751

752

753

754

755

756

757

758

759

760

761

762 copper complexation of dissolved organic matter in saline-alkali soils using fluorescence excitation-emission matrix and parallel factor analysis. J Soils Sediments 15(7):1473-1482. https://doi.org/10.1007/s11368-015-1113-7

Han N, Thompson ML (1999) Copper-Binding Ability of Dissolved Organic Matter Derived from Anaerobically Digested Biosolids. Journal of Environmental Quality 28(3):939944. https://doi.org/10.2134/jeq1999.00472425002800030026x

Han N, Thompson ML (2003) Impact of Dissolved Organic Matter on Copper Mobility in Aquifer Material. Journal of Environmental Quality 32(5):1829-1836. https://doi.org/10.2134/jeq2003.1829

Harmsen J (2007) Measuring Bioavailability: From a Scientific Approach to Standard Methods. Journal of environmental quality 36:1420-8. https://doi.org/10.2134/jeq2006.0492

He W, Lee J-H, Hur J (2016) Anthropogenic signature of sediment organic matter probed by UV-Visible and fluorescence spectroscopy and the association with heavy metal enrichment.

Chemosphere 150:184-193. https://doi.org/10.1016/j.chemosphere.2016.01.116

Helling B, Reinecke SA, Reinecke AJ (2000) Effects of the Fungicide Copper Oxychloride on the Growth and Reproduction of Eisenia fetida (Oligochaeta). Ecotoxicology and Environmental Safety 46(1):108-116. https://doi.org/10.1006/eesa.1999.1880

Helms JR, Stubbins A, Ritchie JD, Minor EC, Kieber DJ, Mopper K (2008) Absorption spectral slopes and slope ratios as indicators of molecular weight, source, and photobleaching of chromophoric dissolved organic matter. Limnology and Oceanography 53(3):955-969. https://doi.org/10.4319/1o.2008.53.3.0955 
763 Hudson N, Baker A, Reynolds D (2007) Fluorescence analysis of dissolved organic matter in

764

765

766

767

768

769

770

771

772

773

774

775

776

777

778

779

780

781

782

783

784 natural, waste and polluted waters - a review. River Research and Applications 23(6):631-649. https://doi.org/10.1002/rra.1005

Huguet A, Vacher L, Relexans S, Saubusse S, Froidefond JM, Parlanti E (2009) Properties of fluorescent dissolved organic matter in the Gironde Estuary. Organic Geochemistry 40(6):706-719. https://doi.org/10.1016/j.orggeochem.2009.03.002

Husson F, Josse J, Lê S (2008) FactoMineR: An R Package for Multivariate Analysis. Journal of Statistical Software 25. https://doi.org/10.18637/jss.v025.i01

Inamdar S, Singh S, Dutta S, Levia D, Mitchell M, Scott D, Bais H, McHale P (2011) Fluorescence characteristics and sources of dissolved organic matter for stream water during storm events in a forested mid-Atlantic watershed. Journal of Geophysical Research: Biogeosciences 116(G3). https://doi.org/10.1029/2011JG001735

ISO 2006 Soil quality - Requirements and guidance for the selection and application of methods for the assessment of bioavailability of contaminants in soil and soil materials

Jaffé R, Cawley KM, Yamashita Y (2014) Applications of Excitation Emission Matrix Fluorescence with Parallel Factor Analysis (EEM-PARAFAC) in Assessing Environmental Dynamics of Natural Dissolved Organic Matter (DOM) in Aquatic Environments: A Review. In: Rosario-Ortiz F (ed) ACS Symposium Series. American Chemical Society, Washington, DC, pp 27-73

Jones D, Willett V (2006) Experimental evaluation of methods to quantify dissolved organic nitrogen (DON) and dissolved organic carbon (DOC) in soil. Soil Biology and Biochemistry 38(5):991-999. https://doi.org/10.1016/j.soilbio.2005.08.012 
Juang K-W, Lee Y-I, Lai H-Y, Wang C-H, Chen B-C (2012) Copper accumulation, translocation, and toxic effects in grapevine cuttings. Environ Sci Pollut Res Int 19(4):1315-1322. https://doi.org/10.1007/s11356-011-0657-3

788

789

790

791

792

793

794

795

796

797

798

799

800

801

802

803

804

805

806

Kader M, Lamb DT, Wang L, Megharaj M, Naidu R (2016) Predicting copper phytotoxicity based on pore-water pCu. Ecotoxicology 25(3):481-490. https://doi.org/10.1007/s10646-015-1605-7

Kalbitz K, Schmerwitz J, Schwesig D, Matzner E (2003) Biodegradation of soil-derived dissolved organic matter as related to its properties. Geoderma 113(3):273-291. https://doi.org/10.1016/S0016-7061(02)00365-8

Karimi B, Masson V, Guilland C, Leroy E, Pellegrinelli S, Giboulot E, Maron P-A, Ranjard L (2021) Ecotoxicity of copper input and accumulation for soil biodiversity in vineyards. Environ Chem Lett. https://doi.org/10.1007/s10311-020-01155-x

Kelepertzis E, Massas I, Fligos G, Panagiotou M, Argyraki A (2017) Copper accumulation in vineyard soils from Nemea, Greece. Bulletin of the Geological Society of Greece 50:2192. https://doi.org/10.12681/bgsg. 14275

Kikuchi T, Fujii M, Terao K, Jiwei R, Lee YP, Yoshimura C (2017) Correlations between aromaticity of dissolved organic matter and trace metal concentrations in natural and effluent waters: A case study in the Sagami River Basin, Japan. Science of The Total Environment 576:36-45. https://doi.org/10.1016/j.scitotenv.2016.10.068

Kinniburgh DG, Milne CJ, Benedetti MF, Pinheiro JP, Filius J, Koopal LK, Van Riemsdijk WH (1996) Metal Ion Binding by Humic Acid: Application of the NICA-Donnan Model. Environ Sci Technol 30(5):1687-1698. https://doi.org/10.1021/es950695h 
Kolbas A, Marchand L, Herzig R, Nehnevajova E, Mench M (2014) Phenotypic seedling responses of a metal-tolerant mutant line of sunflower growing on a $\mathrm{Cu}$-contaminated soil series: potential uses for biomonitoring of $\mathrm{Cu}$ exposure and phytoremediation. Plant Soil 376(1):377-397. https://doi.org/10.1007/s11104-013-1974-8

Komárek M, Čadková E, Chrastný V, Bordas F, Bollinger J-C (2010) Contamination of vineyard soils with fungicides: A review of environmental and toxicological aspects. Environment International 36(1):138-151. https://doi.org/10.1016/j.envint.2009.10.005

Koopal LK, Saito T, Pinheiro JP, Riemsdijk WH van (2005) Ion binding to natural organic matter: General considerations and the NICA-Donnan model. Colloids and Surfaces A: Physicochemical and Engineering Aspects 265(1):40-54. https://doi.org/10.1016/j.colsurfa.2004.11.050

Küpper H, Götz B, Mijovilovich A, Küpper FC, Meyer-Klaucke W (2009) Complexation and Toxicity of Copper in Higher Plants. I. Characterization of Copper Accumulation, Speciation, and Toxicity in Crassula helmsii as a New Copper Accumulator. Plant Physiology 151(2):702-714. https://doi.org/10.1104/pp.109.139717

Leenheer JA (1981) Comprehensive approach to preparative isolation and fractionation of dissolved organic carbon from natural waters and wastewaters. Environ Sci Technol 15(5):578-587. https://doi.org/10.1021/es00087a010

Li S, Li M, Wang G, Sun X, Xi B, Hu Z (2019) Compositional and chemical characteristics of dissolved organic matter in various types of cropped and natural Chinese soils. Chem Biol Technol Agric 6(1):20. https://doi.org/10.1186/s40538-019-0158-z 
830

831

832

834

835

836

837

838

839

840

841

842

843

844

845

846

847

848

849

850

Manceau A, Matynia A (2010) The nature of Cu bonding to natural organic matter. Geochimica et Cosmochimica Acta 74(9):2556-2580. https://doi.org/10.1016/j.gca.2010.01.027

Meeussen JCL (2003) ORCHESTRA: An Object-Oriented Framework for Implementing Chemical Equilibrium Models. Environ Sci Technol 37(6):1175-1182. https://doi.org/10.1021/es025597s

McBride M, Sauve S, Hendershot W (1997) Solubility control of $\mathrm{Cu}, \mathrm{Zn}, \mathrm{Cd}$ and $\mathrm{Pb}$ in contaminated soils. European Journal of Soil Science 48(2):337-346. https://doi.org/10.1111/j.1365-2389.1997.tb00554.x

McBride MB (1989) Reactions Controlling Heavy Metal Solubility in Soils. In: Stewart BA (ed) Advances in Soil Science: Volume 10. Springer, New York, NY, pp 1-56

McBride MB, Blasiak JJ (1979) Zinc and Copper Solubility as a Function of pH in an Acid Soill. Soil Science Society of America Journal 43(5):866. https://doi.org/10.2136/sssaj1979.03615995004300050009x

McKnight DM, Boyer EW, Westerhoff PK, Doran PT, Kulbe T, Andersen DT (2001) Spectrofluorometric characterization of dissolved organic matter for indication of precursor organic material and aromaticity. Limnology and Oceanography 46(1):3848. https://doi.org/10.4319/1o.2001.46.1.0038

Michaud AM, Bravin MN, Galleguillos M, Hinsinger P (2007) Copper uptake and phytotoxicity as assessed in situ for durum wheat (Triticum turgidum durum L.) cultivated in Cu-contaminated, former vineyard soils. Plant Soil 298(1):99-111. https://doi.org/10.1007/s11104-007-9343-0 
Michaud AM, Chappellaz C, Hinsinger P (2008) Copper phytotoxicity affects root elongation and iron nutrition in durum wheat (Triticum turgidum durum L.). Plant Soil 310(1):151165. https://doi.org/10.1007/s11104-008-9642-0

Milne CJ, Kinniburgh DG, Tipping E (2001) Generic NICA-Donnan Model Parameters for Proton Binding by Humic Substances. Environ Sci Technol 35(10):2049-2059. https://doi.org/10.1021/es000123j

Milne CJ, Kinniburgh DG, van Riemsdijk WH, Tipping E (2003) Generic NICA-Donnan Model Parameters for Metal-Ion Binding by Humic Substances. Environ Sci Technol 37(5):958-971. https://doi.org/10.1021/es0258879

Musadji NY, Lemée L, Caner L, Porel G, Poinot P, Geffroy-Rodier C (2020) Spectral characteristics of soil dissolved organic matter: Long-term effects of exogenous organic matter on soil organic matter and spatial-temporal changes. Chemosphere 240:124808. https://doi.org/10.1016/j.chemosphere.2019.124808

Navel A, Martins JMF (2014) Effect of long term organic amendments and vegetation of vineyard soils on the microscale distribution and biogeochemistry of copper. Science of The Total Environment 466-467:681-689. https://doi.org/10.1016/j.scitotenv.2013.07.064

Ohno T, Fernandez IJ, Hiradate S, Sherman JF (2007) Effects of soil acidification and forest type on water soluble soil organic matter properties. Geoderma 140(1):176-187. https://doi.org/10.1016/j.geoderma.2007.04.004

Oustriere N, Marchand L, Galland W, Gabbon L, Lottier N, Motelica M, Mench M (2016) Influence of biochars, compost and iron grit, alone and in combination, on copper solubility and phytotoxicity in a Cu-contaminated soil from a wood preservation site. 
874

875

876

877

878

879

880

881

882

883

884

885

886 https://doi.org/10.1016/j.scitotenv.2016.05.091

Ouzounidou G (1995) Responses of maize (Zea mays L.) plants to copper stress-I. Growth, mineral content and ultrastructure of roots. Environmental and Experimental Botany 35(2):167-176. https://doi.org/10.1016/0098-8472(94)00049-B

Parat C, Chaussod R, Leveque J, Dousset S, Andreux F (2002) The relationship between copper accumulated in vineyard calcareous soils and soil organic matter and iron. Eur J Soil Science 53(4):663-670. https://doi.org/10.1046/j.1365-2389.2002.00478.x

Qiu H, Vijver MG, He E, Peijnenburg WJGM (2013) Predicting copper toxicity to different earthworm species using a multicomponent Freundlich model. Environ Sci Technol 47(9):4796-4803. https://doi.org/10.1021/es305240n

R core Team (2020) R A Lang. Environ. Stat. Comput. R Found. Stat. Comput, Vienna, Austria URL. https://www.r-project.org/

Recatalá L, Sacristán D, Arbelo C, Sánchez J (2012) Can a Single and Unique Cu Soil Quality Standard be Valid for Different Mediterranean Agricultural Soils under an Accumulator Crop? Water, Air, \& Soil Pollution 223. https://doi.org/10.1007/s11270-011-0960-0

Ren Z-L, Tella M, Bravin MN, Comans RNJ, Dai J, Garnier J-M, Sivry Y, Doelsch E, Straathof A, Benedetti MF (2015) Effect of dissolved organic matter composition on metal speciation in soil solutions. Chemical Geology 398:61-69. https://doi.org/10.1016/j.chemgeo.2015.01.020 
894 Ritsema CJ (1993) Estimation of activity coefficients of individual ions in solutions with ionic

895

896

897

898

899

900

901

902

903

904

905

906

907

908

909

910

911

912

913

914

915 strengths up to $0.3 \mathrm{~mol} \mathrm{dm}-3$. Journal of Soil Science 44(2):307-315. https://doi.org/10.1111/j.1365-2389.1993.tb00454.x

Romero CM, Engel RE, D’Andrilli J, Chen C, Zabinski C, Miller PR, Wallander R (2017) Bulk optical characterization of dissolved organic matter from semiarid wheat-based cropping systems.

Geoderma $306: 40-49$. https://doi.org/10.1016/j.geoderma.2017.06.029

Römkens PFAM, Dolfing J (1998) Effect of Ca on the Solubility and Molecular Size Distribution of DOC and Cu Binding in Soil Solution Samples. Environmental Science \& Technology 32(3):363-369. https://doi.org/10.1021/es970437f

Sacristán D, Viscarra Rossel RA, Recatalá L (2016) Proximal sensing of Cu in soil and lettuce using portable X-ray fluorescence spectrometry. Geoderma 265:6-11. https://doi.org/10.1016/j.geoderma.2015.11.008

Sauvé S, Cook N, Hendershot WH, McBride MB (1996) Linking plant tissue concentrations and soil copper pools in urban contaminated soils. Environmental Pollution 94(2):153157. https://doi.org/10.1016/S0269-7491(96)00081-4

Sauvé S, Dumestre A, McBride M, Hendershot W (1998) Derivation of soil quality criteria using predicted chemical speciation of $\mathrm{Pb} 2+$ and $\mathrm{Cu} 2+$. Environmental Toxicology and Chemistry 17(8):1481-1489. https://doi.org/10.1002/etc.5620170808

Sauvé S, Hendershot W, Allen HE (2000) Solid-Solution Partitioning of Metals in Contaminated Soils: Dependence on pH, Total Metal Burden, and Organic Matter. Environ Sci Technol 34(7):1125-1131. https://doi.org/10.1021/es9907764 
916 Sauvé S, McBride MB, Hendershot WH (1995) Ion-selective electrode measurements of

917

918

919

920

921

922

923

924

925

926

927

928

929

930

931

932

933

934

935

936 copper(II) activity in contaminated soils. Archives of Environmental Contamination and Toxicology 29(3):373-379. https://doi.org/10.1007/BF00212503

Sauvé S, McBride MB, Norvell WA, Hendershot WH (1997) Copper Solubility and Speciation of In Situ Contaminated Soils: Effects of Copper Level, pH and Organic Matter. Water, Air, \& Soil Pollution 100(1):133-149. https://doi.org/10.1023/A:1018312109677

Sun R, Song C, Sun Y, Wang Q, Liu H, Wang J (2020) Agricultural Soil Organic Matters and Microbiome Are Shaped by Management and Hedgerows. Agronomy 10(9):1316. https://doi.org/10.3390/agronomy10091316

Supriatin S, Terrones CA, Bussink W, Weng L (2015) Drying effects on selenium and copper in $0.01 \mathrm{M}$ calcium chloride soil extractions. Geoderma 255-256:104-114. https://doi.org/10.1016/j.geoderma.2015.04.021

Swift MJ, Heal OW, Anderson JM (1979) Decomposition in terrestrial ecosystems. Studies in ecology (USA)

Tait TN, Cooper CA, McGeer JC, Wood CM, Smith DS (2016) Influence of dissolved organic matter (DOM) source on copper speciation and toxicity to Brachionus plicatilis. Environ Chem 13(3):496. https://doi.org/10.1071/EN15123

Tang J, Wang W, Yang L, Cao C, Li X (2019) Variation in quantity and chemical composition of soil dissolved organic matter in a peri-urban critical zone observatory watershed in Eastern China. Science of The Total Environment 688:622-631. https://doi.org/10.1016/j.scitotenv.2019.06.270 
Temminghoff EJM, Van Der Zee SE a. TM, Keizer MG (1994) The influence of pH on the desorption and speciation of copper in a sandy soil. Soil Science 158(6):398-408

Trevors JT, Cotter CM (1990) Copper toxicity and uptake in microorganisms. Journal of Industrial Microbiology 6(2):77-84. https://doi.org/10.1007/BF01576426

Verweij W, Glazewski R, Haan HD (1992) Speciation of copper in relation to its bioavailability. Chemical Speciation $\&$ Bioavailability $4(2): 43-51$. https://doi.org/10.1080/09542299.1992.11083177

Wei T, Simko V (2021) R package "corrplot": Visualization of a Correlation Matrix. https://github.com/taiyun/corrplot. Accessed 5 Jan 2021

Weishaar JL, Aiken GR, Bergamaschi BA, Fram MS, Fujii R, Mopper K (2003) Evaluation of Specific Ultraviolet Absorbance as an Indicator of the Chemical Composition and Reactivity of Dissolved Organic Carbon. Environ Sci Technol 37(20):4702-4708. https://doi.org/10.1021/es030360x

Weng L, Temminghoff EJM, Lofts S, Tipping E, Van Riemsdijk WH (2002) Complexation with Dissolved Organic Matter and Solubility Control of Heavy Metals in a Sandy Soil. $\begin{array}{lllll}\text { Environmental } & \text { Science } & \& & \text { Technology } & 36(22): 4804\end{array}$ 4810.https://doi.org/10.1021/es0200084

Xu H, Zou L, Guan D, Li W, Jiang H (2019) Molecular weight-dependent spectral and metal binding properties of sediment dissolved organic matter from different origins. Science of The Total Environment 665:828-835. https://doi.org/10.1016/j.scitotenv.2019.02.186 
958 Yang L, Hur J (2014) Critical evaluation of spectroscopic indices for organic matter source

959

960

961

962

963

964

965

966

967

968

969

970

971

972

973

974

975

976

977

978 tracing via end member mixing analysis based on two contrasting sources. Water Research 59:80-89. https://doi.org/10.1016/j.watres.2014.04.018

Yeh Y-L, Yeh K-J, Hsu L-F, Yu W-C, Lee M-H, Chen T-C (2014) Use of fluorescence quenching method to measure sorption constants of phenolic xenoestrogens onto humic fractions from sediment. Journal of Hazardous Materials 277:27-33. https://doi.org/10.1016/j.jhazmat.2014.03.057

Yruela I (2009) Copper in plants: acquisition, transport and interactions. Functional Plant Biol 36(5):409. https://doi.org/10.1071/FP08288

Yruela I (2005) Copper in plants. Brazilian Journal of Plant Physiology 17(1):145-156. https://doi.org/10.1590/S1677-04202005000100012

Zhang S, Chen X-W, Ye Q, Zhang Z-T, Kong S-F, Cao C, Wang J-J (2020) Dissolved Metal(loid) Concentrations and Their Relations with Chromophoric and Fluorescent Dissolved Organic Matter in an Urban River in Shenzhen, South China. Water 12(1):281. https://doi.org/10.3390/w12010281

Zsolnay A (1996) Dissolved Humus in Soil Waters. In: Humic Substances in Terrestrial Ecosystems. Elsevier, pp 171-223

Zsolnay A, Baigar E, Jimenez M, Steinweg B, Saccomandi F (1999) Differentiating with fluorescence spectroscopy the sources of dissolved organic matter in soils subjected to drying. Chemosphere 38(1):45-50. https://doi.org/10.1016/S0045-6535(98)00166-0 
Figure 1
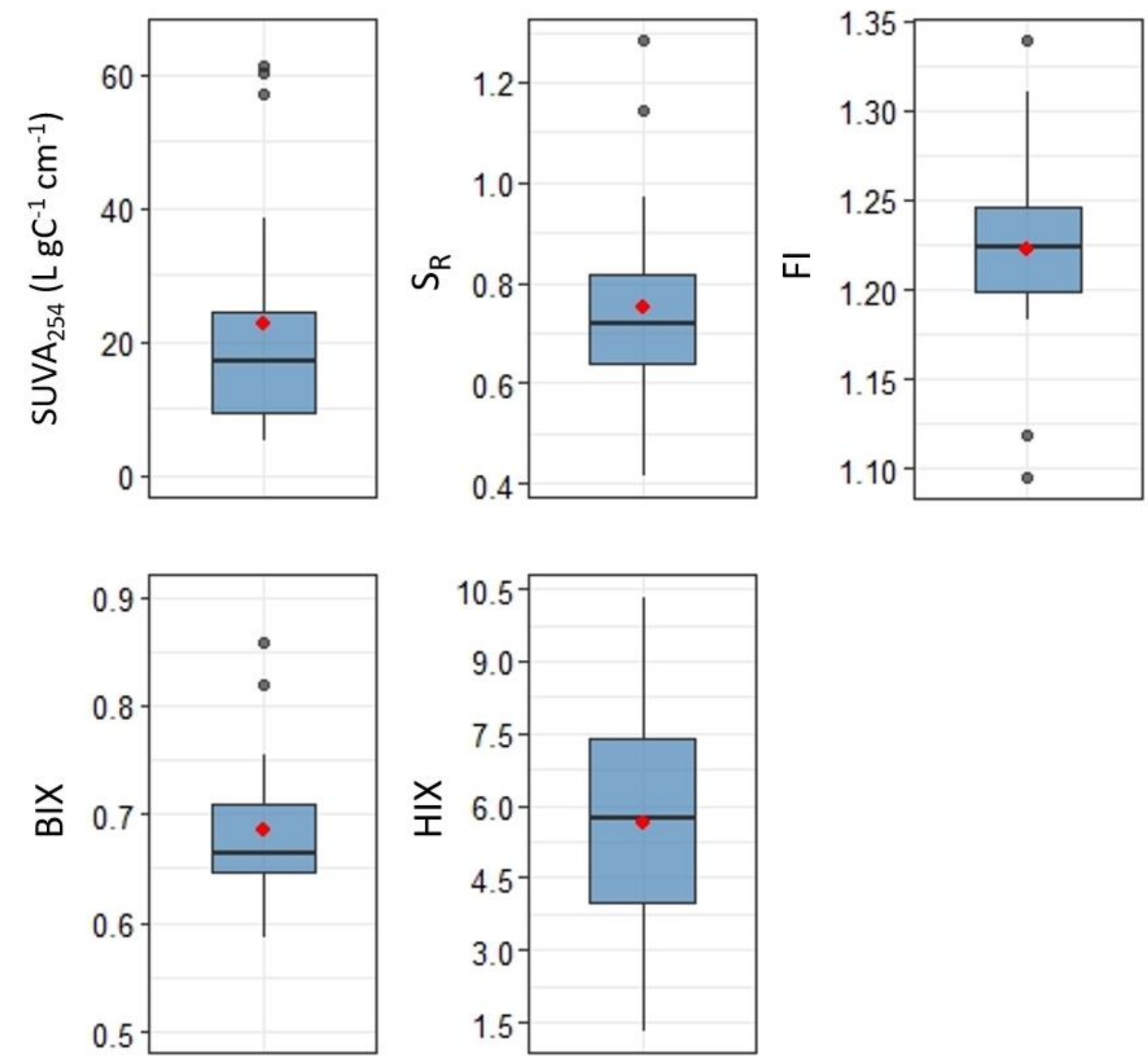
Figure 2

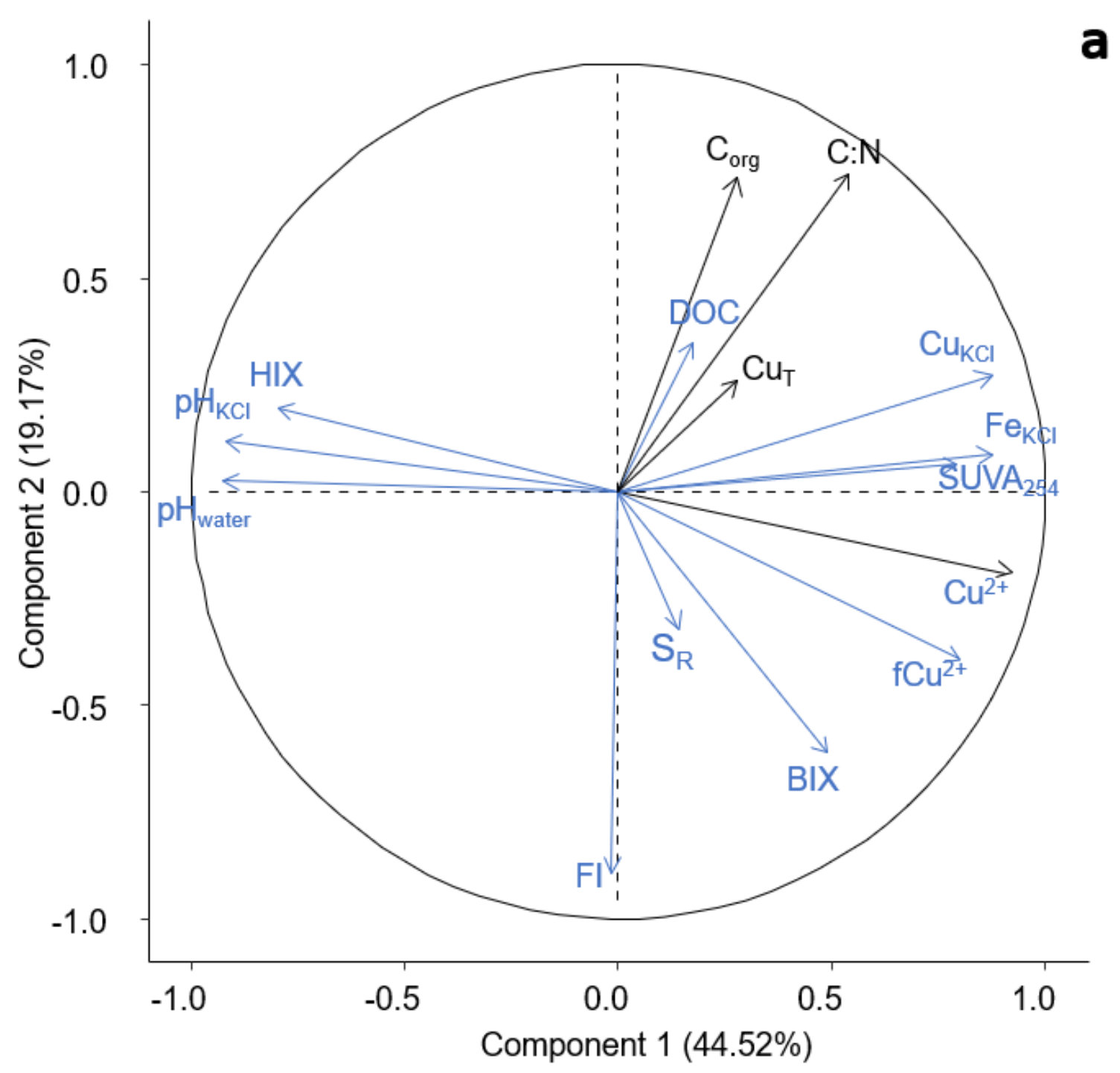


Figure 2

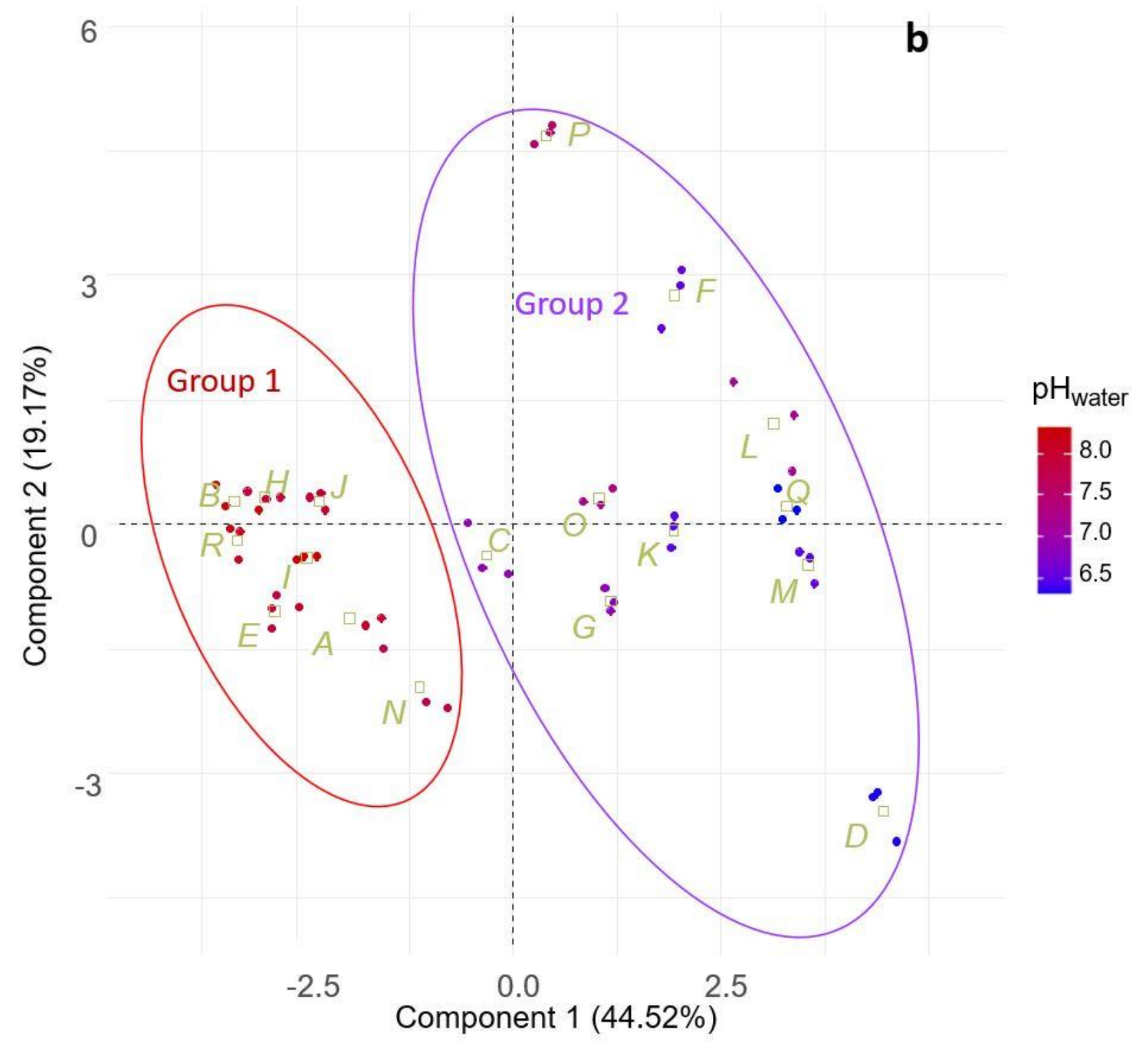


Figure 3

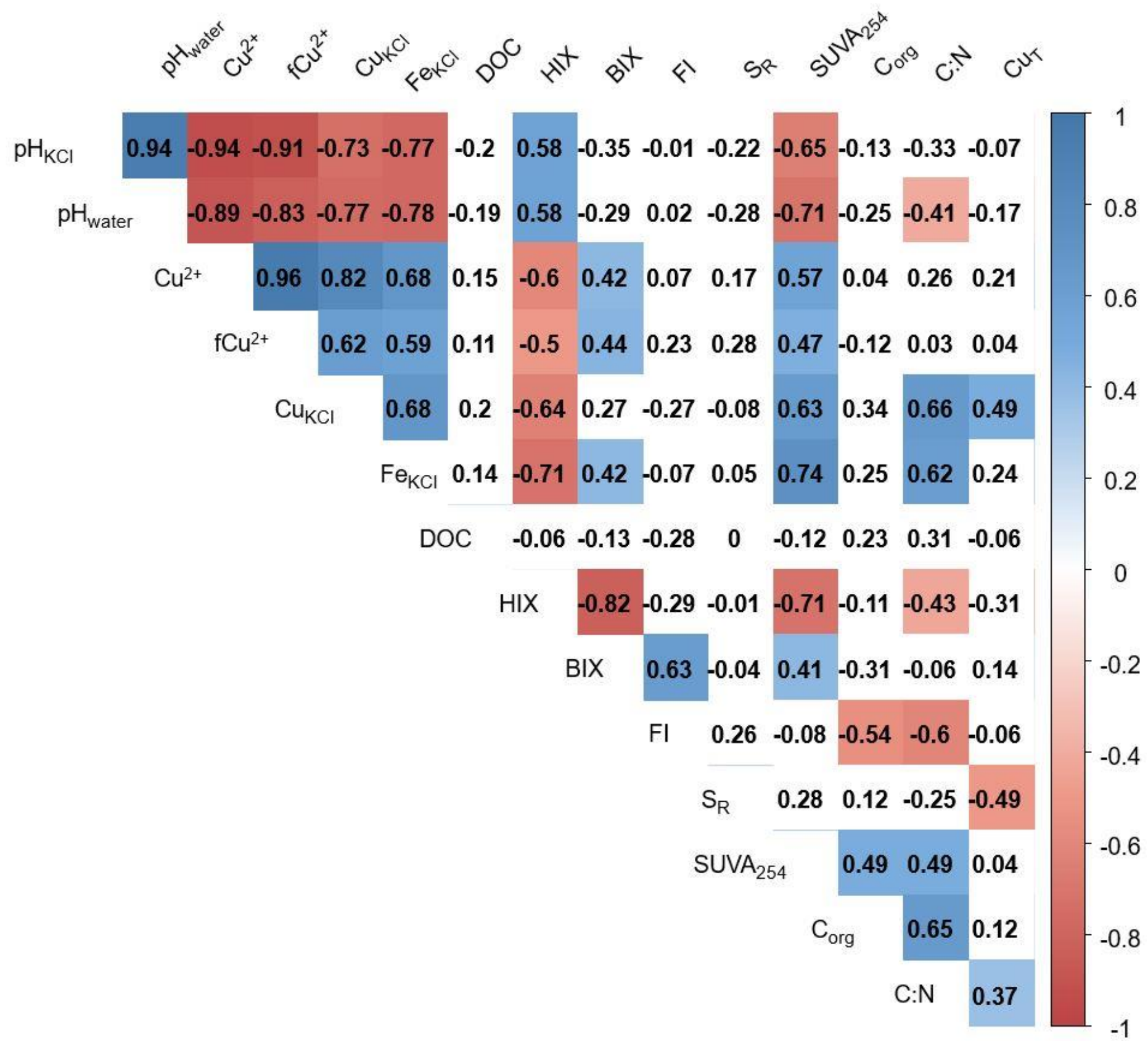


Figure 5
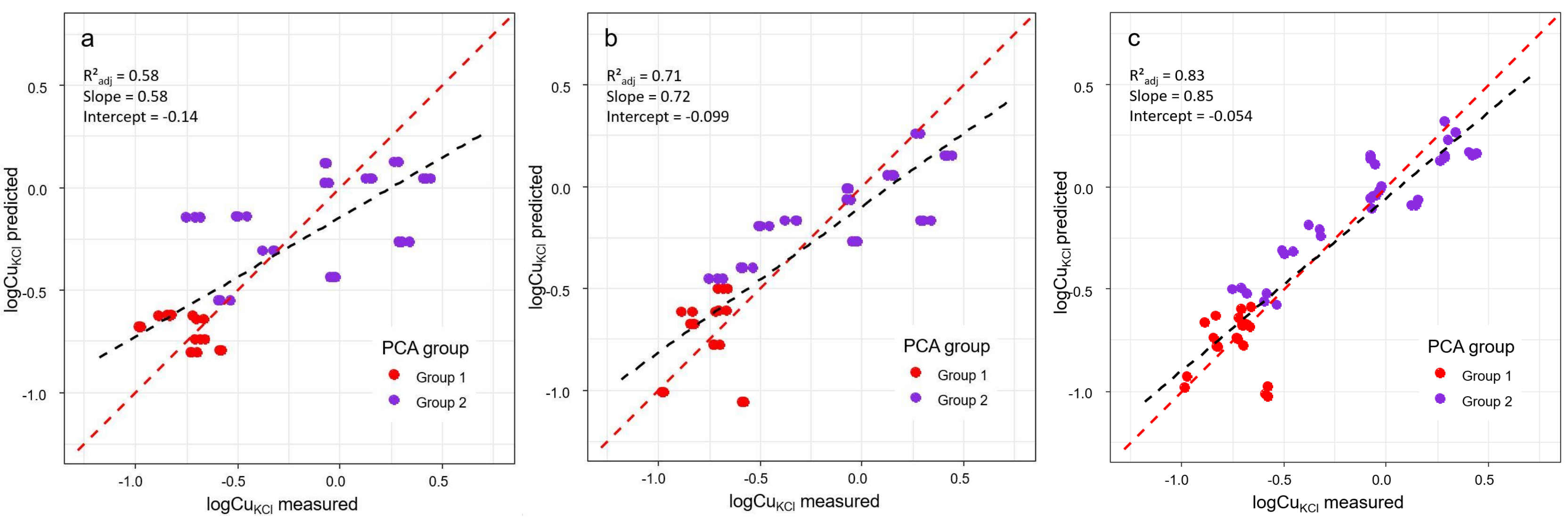
Figure 5
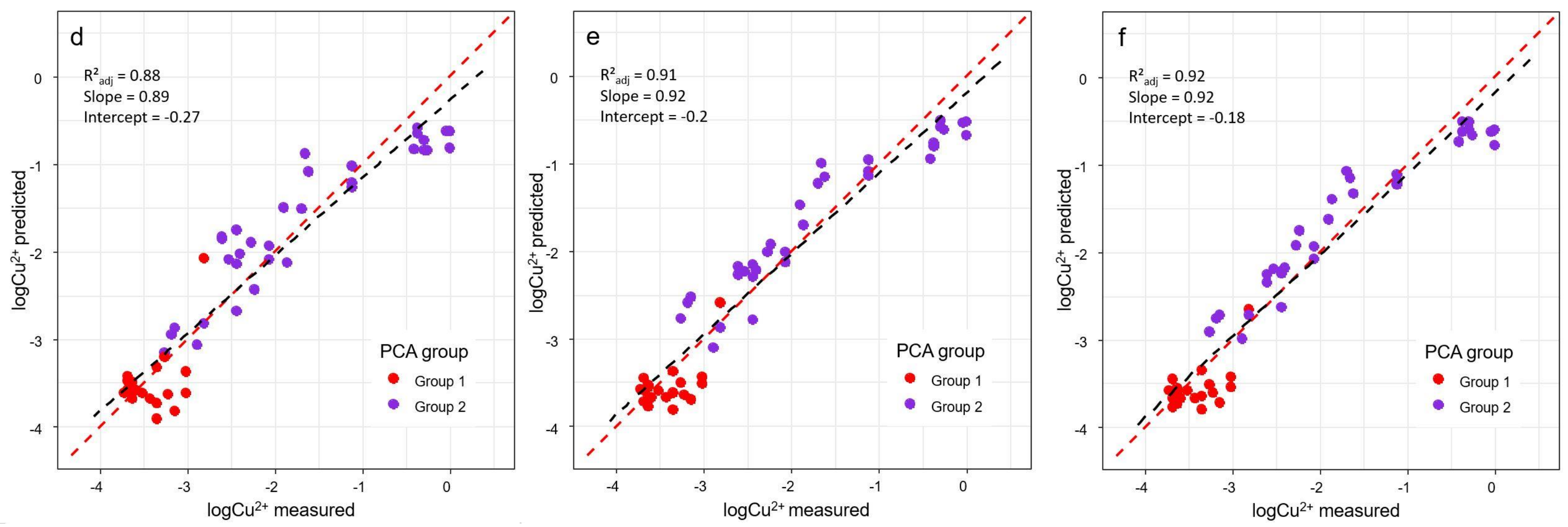


\section{Figure captions}

Fig. 1: Distribution of DOM optical parameters (mean of replicates), the red points represent the mean values of all the soils

Fig. 2: Principal component analysis (PCA) of soil solution chemistry and $\mathrm{Cu}$ availability proxies in the dataset. All the variables except $\mathrm{pH}_{\text {water }}$ and $\mathrm{pH}_{\mathrm{KCl}}$ were log-transformed. The correlation plot (a) shows the contribution of each variable to the two first principal components. The soil variables are shown in black, the extract variables in blue. Soil samples (grouped in triplicate) are coloured according to their $\mathrm{pH}_{\text {water }}$ values (b)

Fig. 3: Correlation matrix between soil properties $\left(\mathrm{pH}_{\text {water }}, \mathrm{C}_{\mathrm{org}}, \mathrm{C}: \mathrm{N}, \mathrm{Cu}_{\mathrm{T}}\right)$, solution parameters: $\mathrm{pH}$ of the extracts $\left(\mathrm{pH}_{\mathrm{KCl}}\right)$, free ionic concentrations $\left(\mathrm{Cu}^{2+}\right)$, free ionic fractions $\left(\mathrm{fCu}^{2+}\right)$, total dissolved metals $\left(\mathrm{Cu}_{\mathrm{KCl}}, \mathrm{Fe}_{\mathrm{KCl}}\right)$ and DOM properties (DOC, HIX, BIX, FI, S $\left.\mathrm{R}, \mathrm{SUVA}_{254}\right)$. The colored boxes represent significant correlations $(\mathrm{p}<0.01)$

Fig. 4: Total $\mathrm{Cu}$ concentrations in extracts $\left(\mathrm{Cu}_{\mathrm{KCl}}\right)$ as a function of total $\mathrm{Cu}$ in soils $\mathrm{Cu}_{\mathrm{T}}$ (a) and $\mathrm{pH}$ of the soils $\left(\mathrm{pH}_{\text {water }}\right)(\mathrm{b})$; free ionic $\mathrm{Cu}$ concentrations $\left(\mathrm{Cu}^{2+}\right)$ as a function of total $\mathrm{Cu}$ concentrations in extracts (c) and $\mathrm{pH}$ of the extracts $\left(\mathrm{pH}_{\mathrm{KCl}}\right)(\mathrm{d})$. The log-log plot is shown in (c) and only the y-axis is log-transformed in (b) and (d)

Fig. 5: Comparison of the multilinear models predicting $\mathrm{Cu}_{\mathrm{KCl}}(\mathrm{a}, \mathrm{b}, \mathrm{c})$ and $\mathrm{Cu}^{2+}$ concentrations (d, e, f) in the $0.01 \mathrm{M} \mathrm{KCl} \mathrm{extracts.} \mathrm{The} \mathrm{dashed} \mathrm{red} \mathrm{line} \mathrm{represents} \mathrm{the} \mathrm{1:1} \mathrm{line,} \mathrm{the} \mathrm{dashed} \mathrm{black}$ line represents the regression line 


\section{Tables}

Table 1: Chemical properties of the 18 vineyard soils analysed in this study. $\mathrm{C}_{\text {org }}$ stands for organic carbon, $\mathrm{Cu}_{\mathrm{T}}$ for total $\mathrm{Cu}$. Carbonate values $<1$ were not quantifiable

\begin{tabular}{|c|c|c|c|c|c|c|c|}
\hline \multirow[t]{2}{*}{$\begin{array}{l}\text { Soil } \\
\text { id }\end{array}$} & \multirow[t]{2}{*}{ AOC Zone } & \multirow[t]{2}{*}{$\begin{array}{c}\text { Soil } \\
\text { classification } \\
(\text { WRB })\end{array}$} & \multirow{2}{*}{$\begin{array}{c}\text { Cut } \\
\mathrm{mg} \mathrm{kg}^{-1}\end{array}$} & \multirow[t]{2}{*}{ pHwater } & \multirow{2}{*}{$\begin{array}{c}\mathrm{CaCO}_{3} \\
\mathrm{~g} \mathrm{~kg}^{-1}\end{array}$} & \multirow{2}{*}{$\begin{array}{c}\text { Corg } \\
\mathrm{g} \mathrm{kg}^{-1}\end{array}$} & \multirow[t]{2}{*}{$C: N$} \\
\hline & & & & & & & \\
\hline $\mathbf{A}$ & $\begin{array}{l}\text { Blaye Côtes } \\
\text { de Bordeaux }\end{array}$ & Cambisol & 28 & 8.1 & $<1$ & 9.9 & 10.6 \\
\hline B & $\begin{array}{l}\text { Blaye Côtes } \\
\text { de Bordeaux }\end{array}$ & Cambisol & 35 & 8.3 & 27.6 & 13.7 & 10.9 \\
\hline C & $\begin{array}{l}\text { Blaye Côtes } \\
\text { de Bordeaux }\end{array}$ & Luvic Camisol & 35 & 6.9 & $<1$ & 10.2 & 11.4 \\
\hline D & $\begin{array}{l}\text { Bordeaux } \\
\text { supérieur }\end{array}$ & Luvisol & 73 & 6.3 & $<1$ & 10.5 & 11.5 \\
\hline $\mathbf{E}$ & $\begin{array}{l}\text { Blaye Côtes } \\
\text { de Bordeaux }\end{array}$ & Cambisol & 80 & 7.9 & $<1$ & 8.3 & 10.7 \\
\hline $\mathbf{F}$ & Graves & Podzosol & 84 & 6.5 & $<1$ & 16.9 & 15.3 \\
\hline $\mathbf{G}$ & $\begin{array}{l}\text { Bordeaux } \\
\text { supérieur }\end{array}$ & Luvisol & 89 & 6.9 & $<1$ & 19.2 & 11.7 \\
\hline $\mathbf{H}$ & $\begin{array}{l}\text { Bordeaux } \\
\text { supérieur }\end{array}$ & Luvisol & 103 & 7.9 & 3.2 & 12.6 & 10.6 \\
\hline I & Graves & Cambisol & 104 & 8.3 & 19.5 & 7.5 & 11.5 \\
\hline $\mathbf{J}$ & $\begin{array}{l}\text { Blaye Côtes } \\
\text { de Bordeaux }\end{array}$ & Luvisol & 110 & 8 & 1.1 & 11.3 & 11.6 \\
\hline $\mathbf{K}$ & $\begin{array}{l}\text { Blaye Côtes } \\
\text { de Bordeaux }\end{array}$ & Podzosol & 121 & 6.5 & $<1$ & 11.8 & 13.0 \\
\hline $\mathbf{L}$ & Graves & Leptosol & 155 & 7.1 & $<1$ & 14.6 & 15.5 \\
\hline $\mathbf{M}$ & $\begin{array}{l}\text { Blaye Côtes } \\
\text { de Bordeaux }\end{array}$ & Luvisol & 175 & 6.5 & $<1$ & 9.3 & 11.9 \\
\hline $\mathbf{N}$ & $\begin{array}{l}\text { Blaye Côtes } \\
\text { de Bordeaux }\end{array}$ & Luvisol & 176 & 7.8 & $<1$ & 5.4 & 11.7 \\
\hline $\mathbf{O}$ & $\begin{array}{l}\text { Blaye Côtes } \\
\text { de Bordeaux }\end{array}$ & Luvisol & 181 & 7.3 & $<1$ & 15.6 & 12.6 \\
\hline $\mathbf{P}$ & Graves & Leptosol & 193 & 7.5 & $<1$ & 30.8 & 17.4 \\
\hline
\end{tabular}




\begin{tabular}{cccccccc}
$\mathbf{Q}$ & $\begin{array}{c}\text { Blaye Côtes } \\
\text { de Bordeaux }\end{array}$ & Luvisol & 195 & 6.3 & $<1$ & 13.3 & 12.6 \\
$\mathbf{R}$ & $\begin{array}{c}\text { Blaye Côtes } \\
\text { de Bordeaux }\end{array}$ & Cambisol & 238 & 8.2 & 30.4 & 10.6 & 10.3 \\
\hline
\end{tabular}


Table 2: Values of total $\mathrm{Cu}$ in solution and $\mathrm{Cu}^{2+}$ reported as toxicity thresholds in the literature, compared with the maximum values found in the present study

\begin{tabular}{llll}
\cline { 2 - 3 } & Toxicity thresholds & $\begin{array}{l}\text { Values } \\
(\mu \mathrm{M})\end{array}$ & References \\
\hline \multirow{3}{*}{$\begin{array}{l}\text { Total } \mathrm{Cu} \text { in solution } \\
\text { this study) }\end{array}$} & Max value in this study & $\mathbf{2 . 6 4}$ & \\
& in $\mathrm{IC}_{50}$ grapevine & 3.94 & Juang et al. 2012 \\
& $\mathrm{IC}_{50}$ maize & 6.50 & Ouzounidou 1995 \\
& $\mathrm{IC}_{50}$ sunflower & 9.55 & Kolbas et al. 2014 \\
\hline \multirow{3}{*}{ Free ionic $\mathrm{Cu}^{2+}$} & Max value in this study & $\mathbf{0 . 9 4}$ & \\
& EC $_{50}$ durum wheat & 0.06 & Bravin et al. 2010 \\
& EC $_{50}$ cucumber & 2.20 & Kader et al. 2016 \\
& EC $_{50}$ Eisenia fetida & 1.00 & Qiu et al. 2013 \\
\hline
\end{tabular}


Table 3: Best models for predicting $\mathrm{Cu}_{\mathrm{KCl}}$ and $\mathrm{Cu}^{2+}$ in $\mathrm{KCl}$ extracts and associated statistics. $\mathrm{R}^{2}$ adj: adjusted r-squared, RMSE: root mean square error, max VIF: maximum value of the variance inflation factor, $\mathrm{N}$ : number of observations

Statistical significance: $* * *$ for $\mathrm{p}$-value $<0.001, * *$ for $\mathrm{p}$-value $<0.01, *$ for $\mathrm{p}$-value $<0.05$

\begin{tabular}{|c|c|c|c|c|c|}
\hline & Models & $\mathbf{R}^{2}$ adj & $\begin{array}{l}\max \\
\text { VIF }\end{array}$ & $\begin{array}{c}\text { RMSE } \\
(\mu \mathrm{M})\end{array}$ & $\mathbf{N}$ \\
\hline \multirow{3}{*}{$\log _{10} \mathrm{Cu} \mathrm{KCl}=$} & $-0.465 * * * \mathrm{pH}_{\mathrm{water}}+3.066$ (a) & 0.575 & - & 0.28 & 53 \\
\hline & $-0.434 * * * \mathrm{pH}_{\mathrm{water}}+0.615^{* * *} \log _{10} \mathrm{Cu}_{\mathrm{T}}+1.598(\mathrm{~b})$ & 0.707 & 1.02 & 0.23 & 53 \\
\hline & $\begin{array}{l}-0.312 * * * \mathrm{pH}_{\mathrm{water}}+0.443 * * * \log _{10} \mathrm{Cu}_{\mathrm{T}}-7.362 * * * \log _{10} \mathrm{FI} \\
-0.664 * * * \log _{10} \mathrm{HIX}+2.148 \text { (c) }\end{array}$ & 0.832 & 1.91 & 0.17 & 53 \\
\hline \multirow{3}{*}{$\log _{10} \mathrm{Cu}^{2+}=$} & $-1.751 * * * \mathrm{pH}_{\mathrm{KCl}}+9.589(\mathrm{~d})$ & 0.883 & - & 0.40 & 53 \\
\hline & $-1.380 * * * \mathrm{pH}_{\mathrm{KCl}}+0.731 * * * \log _{10} \mathrm{Cu}_{\mathrm{KCl}}-7.307$ (e) & 0.912 & 2.30 & 0.34 & 53 \\
\hline & $\begin{array}{l}-1.316 * * * \mathrm{pH}_{\mathrm{KCl}}+0.73 * * * \log _{10} \mathrm{Cu}_{\mathrm{KCl}}+2.818 * \log _{10} \mathrm{BIX}+ \\
7.338(\mathfrak{f})\end{array}$ & 0.919 & 2.44 & 0.32 & 53 \\
\hline
\end{tabular}

